\section{A dinâmica política do Império: instabilidade, gabinetes e Câmara dos Deputados (1840-1889)}

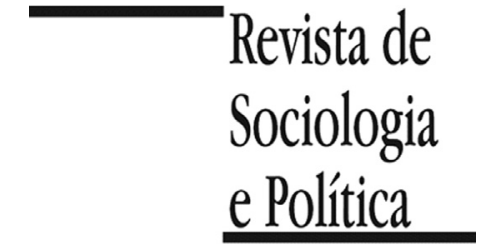

DOI 10.1590/1678-987317256203

\author{
Sérgio Eduardo Ferraz
}

\title{
Resumo
}

O artigo trata da política imperial no Brasil. Sua principal contribuição é delinear compreensão alternativa da dinâmica institucional do "parlamentarismo" da época, sugerindo-se a insuficiência da explicação clássica sobre o período. Propõem-se novas hipóteses sobre duas questões: (1) a instabilidade governamental no Segundo Reinado (1840-1889) e (2) a natureza das relações entre o gabinete e a Câmara dos Deputados no período. Quanto à instabilidade governamental (37 gabinetes em quase 50 anos), a estratégia de pesquisa consistiu no exame, por meio de literatura produzida via cânones diversos e dos anais do Poder Legislativo, de todos os episódios de substituição de gabinetes, inclusive os que implicaram alternância partidária, para mapear as razões políticas associadas a cada afastamento. Construiu-se uma tipologia do fenômeno, ancorada na presença ou ausência de intervenção da Coroa e/ou da Câmara dos Deputados nas substituições. O principal resultado alcançado mostra que tanto a instabilidade dos ministérios como a alternância entre partidos resultou, principalmente, de conflitos entre o Executivo e o Legislativo, em especial a Câmara dos Deputados. O achado desafia as interpretações clássicas que enfatizam o papel da Coroa na substituição dos governos. O conflito entre os gabinetes e a Câmara levou à segunda questão, que trata dessa tensão. Explora-se a hipótese de que a introdução de regras eleitorais "distritalizadas", em substituição às listas, no contexto de um arranjo institucional "centrífugo", alterou importantes incentivos, os quais funcionavam como esteio "centrípeto" do sistema, para agentes políticos relevantes. A mudança agravou as disputas entre ministérios e legislaturas, concorrendo para explicar o fenômeno da instabilidade. A hipótese é corroborada por evidências variadas: (1) o acompanhamento da tramitação na Câmara de projetos orçamentários, entre 1853 e 1860, em legislaturas eleitas por regras diversas, exercício indicador da desigual capacidade de os gabinetes aprovarem suas agendas sob diferentes circunstâncias institucionais, confirmando-se o enfraquecimento ministerial na passagem das listas para os "distritos"; (2) o menor mandato médio dos gabinetes que governaram frente a legislaturas "distritalizadas"; (3) associação entre a queda de gabinetes por pressão do Legislativo e a vigência de regras eleitorais "distritalizadas"; (4) convergência das fontes e da literatura em enfatizar as consequências "centrífugas" da mudança de regime eleitoral. Trilhando essas vias, o artigo inova ao propor uma nova interpretação da experiência parlamentarista do Segundo Reinado (1840-1889) e ao sugerir a fertilidade, para a Ciência Política, de uma agenda de pesquisa que investigue, com as ferramentas analíticas contemporâneas, períodos da história brasileira pouco explorados pela disciplina.

PALAVRAS-CHAVE: instabilidade ministerial; Império; Segundo Reinado; relações Executivo-Legislativo; regras eleitorais.

Recebido em 14 de Janeiro de 2016. Aceito em 31 de Março de 2016.

\section{Introdução ${ }^{1}$}

\author{
1 Beneficiei-me da \\ interlocução sempre fértil, \\ sobre os temas aqui tratados, \\ com Fernando Limongi e \\ Paolo Ricci. Agradeço aos \\ comentários e sugestões \\ valiosas dos pareceristas \\ anônimos da Revista de \\ Sociologia e Política. Sou \\ grato também a Miriam \\ Dolhnikoff, Jairo Nicolau e
}

onstitui praticamente um terreno inexplorado para a Ciência Política o
longo período de existência do Estado brasileiro que antecede a fun-
dação da República. Honrosas exceções à parte, são raros os esforços
sistemáticos para investigar a dinâmica política e institucional dos quase 70
anos em que vigorou o Império.
Isso não quer dizer que um diagnóstico sobre o período não tenha se
produzido e se cristalizado. Oriundo do trabalho dos historiadores, mas migran-
do quase sem qualificações para estudos desenvolvidos no campo das Ciências
Sociais, um entendimento sobre o Império - e, em especial, sobre o seu longo 
Gabriela Nunes Ferreira. Os erros, insuficiências e inconsistências, naturalmente, são de minha inteira responsabilidade.
${ }^{2}$ A exposição detalhada do argumento desenvolvido neste artigo está em "O Império Revisitado: Instabilidade Ministerial, Câmara dos Deputados e Poder Moderador (1840-1889)", tese de doutorado defendida no Departamento de Ciência Política (DCP) da Universidade de São Paulo (USP) em abril de 2012.
Segundo Reinado (1840-1889) - se afirmou e alcança, até hoje, o status de um saber consolidado e objeto de forte consenso.

Para essa perspectiva, a dinâmica política de funcionamento imperial se caracterizou pela centralidade do Poder Moderador. Titularizado pela Coroa, esse Poder foi, nessa interpretação, o árbitro inconteste daquele arranjo institucional e o ator-chave cujos movimentos e decisões explicam, em última análise, o processo político da época.

Assessorado pelo Senado vitalício e pelo Conselho de Estado, o imperador, entronizado no cargo ainda adolescente, aos poucos teria conquistado o domínio das rédeas do arranjo imperial, exercendo controle completo sobre o sistema político, por força das prerrogativas institucionais que a Carta de 1824 lhe garantiu, no contexto de um aparato estatal fortemente centralizado a partir da década de 1840. A contraface do protagonismo da Coroa, nessa interpretação, foi o consenso sobre o caráter meramente formal das instituições representativas no regime imperial, sendo secundarizadas as funções exercidas pela Câmara dos Deputados.

Este artigo contesta essa visão da dinâmica política imperial e propõe um entendimento alternativo dessa fase da história política brasileira. Sem negar a importância do Poder Moderador no arranjo da época, reúnem-se aqui elementos para indicar que características centrais do processo político no Império como a ascensão e a queda dos gabinetes que respondiam pela direção central do Estado - só se tornam inteligíveis quando se introduzem na análise outros fatores, para além da vontade da Coroa e do seu entorno imediato. Com base em uma minuciosa pesquisa que acompanha todos os episódios de substituição de governos no Segundo Reinado, demonstra-se aqui que a rotação dos ministérios entre 1840 e 1889 foi o resultado no mais das vezes da interação entre o Executivo e o Legislativo. Ao contrário do que afirma o consenso convencional sobre o assunto, a sustentação dos gabinetes, durante todo o período, dependeu menos da aquiescência da Coroa do que da capacidade dos titulares do Executivo de assegurarem maiorias na Câmara dos Deputados.

Dizendo de outro modo, quando se analisa, episódio por episódio, os eventos de substituição de ministérios no "parlamentarismo" imperial, vigente durante todo o reinado de Pedro II, descobre-se, não sem surpresa, que o fator mais frequente associado às trocas de governo vem a ser a perda de sustentação legislativa. Mesmo quando estão em jogo alternâncias partidárias - ou seja, quando um gabinete conservador é convocado para suceder um liberal ou vice-versa - vale a regra de que por trás da mudança, na grande maioria dos episódios, está a perda de controle do plenário da Câmara por parte dos incumbentes mais do que a vontade do Poder Moderador.

Este artigo, portanto, revisita a política imperial no Brasil a partir do exame sistemático de um dos aspectos mais importantes daquele arranjo institucional, aquele concernente aos fatores que condicionaram a sobrevivência dos ministérios. Ao fazê-lo, o texto conduz a alterações substantivas no próprio modo de entender a política no Segundo Reinado, sendo essa a sua contribuição central ${ }^{2}$.

Mais especificamente, o trabalho propõe novas hipóteses explicativas sobre dois eixos de questões: a instabilidade governamental no Segundo Reinado (1840-1889) e a natureza das relações entre o gabinete e a Câmara dos Deputados no período.

Quanto à instabilidade ministerial, constata-se que naquele intervalo revezaram-se, à frente do Executivo, 37 gabinetes, constatando-se permanência média no poder de pouco mais de um ano para cada uma das formações governamentais. Buscam-se os motivos dessa rotatividade de governos. Para isso, 
${ }^{3}$ Da literatura neoinstitucionalista, ver Mayhew (1974), Fiorina (1989), Cain, Ferejohn e Fiorina (1987), Krehbiel (1991), Cox e McCubbins (1993), Shugart e Carey (1992) e Limongi (2002; 2003). Para discussão do institucionalismo enquanto método, Diermeier e Krehbiel (2003).

${ }^{4}$ O Segundo Reinado foi regido por sete legislações eleitorais baseadas em regras majoritárias. É útil dicotomizá-las em termos de sistemas de listas provinciais que tinham como circunscrição a província inteira - e sistemas "distritalizados", nos quais a circunscrição se restringiu ao distrito (de um ou três representantes), formado por um grupo de municípios. ${ }^{5}$ A Constituição do Império, de 1824 , só sofreu uma emenda, na década de 1830 (Ato Adicional), e as regras do funcionamento da Câmara cristalizadas nos seus Regimentos Internos permaneceram generosas quanto à distribuição de direitos parlamentares durante o Segundo Reinado. estuda-se cada um dos casos de afastamento, esclarecendo-se as razões de retirada das composições ministeriais.

Ao empreender esse levantamento das circunstâncias das substituições ministeriais, a pesquisa alcança conclusões que desafiam a visão clássica. Em contraste com essa tradição, que enfatiza o papel da Coroa no controle do processo político e a responsabiliza pela instabilidade governamental do Segundo Reinado, os resultados desta investigação evidenciam que conflitos, efetivos ou potenciais, entre o Executivo e o Legislativo, em especial a Câmara dos Deputados, foram o motivo mais frequente associado à queda de gabinetes no período, respondendo por mais da metade dos episódios de retirada examinados.

A constatação desse recorrente conflito, entre a Câmara e os gabinetes, fornece a matéria do segundo eixo do artigo, o qual explora as relações entre gabinetes ministeriais e Legislativo, buscando entender as razões da continuada tensão entre os dois poderes.

A estratégia de pesquisa aprofunda o exame das relações entre Executivo e Câmara no Império a partir de uma perspectiva neoinstitucionalista - pouco explorada no estudo da política imperial no Brasil. Parte-se da noção de que as relações entre Executivo e Legislativo, ou o desempenho dos governos, em termos de sua estabilidade e capacidade de efetivar suas políticas, dependem de três variáveis: (1) o formato do sistema de governo, (2) a legislação eleitoral e (3) a forma de organização interna dos trabalhos legislativos ${ }^{3}$.

À luz do neoinstitucionalismo, considera-se que, no sistema político do Segundo Reinado (1840-1889), as três variáveis-chaves para o desempenho do governo atuaram como vetores "centrífugos", contribuindo para a instabilidade. Isso se dava porque o sistema de governo implicava dependência dupla do gabinete, frente à Coroa e às maiorias legislativas. Por sua vez, as regras do trabalho legislativo exigiam do gabinete, para a aprovação de proposições, a reiterada arregimentação de maiorias, ausentes"atalhos" centralizadores. E, finalmente, por força de que, dos 49 anos estudados, em 28 o sistema eleitoral, sempre majoritário, obedeceu a regras "distritais" (Primeira e Segunda Lei dos Círculos e Lei Saraiva), contra apenas 21 em que se regeu pelo sistema de listas (Decreto de 1824, Instruções de 1842 , Lei de 1846 e Lei do Terço) ${ }^{4}$.

Das três variáveis assinaladas, tanto o sistema de governo como a organização interna legislativa da Câmara foram, entre 1840 e 1889, grosso modo, invariantes ${ }^{5}$, tendo-se, porém, alterado, com frequência, as regras eleitorais, as quais transitaram de um sistema de listas (1840-1856) para um regime "distritalizado", adotado de 1856 até o final da monarquia, salvo o breve período (1876-1881) em que vigorou a "Lei do Terço".

A hipótese explorada é que essa transição das listas para o "distrito" fornece uma chave importante para a compreensão das relações entre os gabinetes e a Câmara dos Deputados no Segundo Reinado, estando na raiz do incremento do conflito entre Executivo e Legislativo, o principal dos fatores associados à instabilidade governamental do período.

Sustenta-se que a troca das listas pelos "distritos", isto é, da grande circunscrição delimitada pela província para pequenas circunscrições determinadas por grupos de municípios, desmontou uma das principais âncoras "centrípetas" do sistema político, com amplas repercussões na política imperial.

A mudança afetou a lógica da competição política e alterou as estruturas de incentivos dos principais agentes políticos, com consequências para o funcionamento da Câmara e suas relações com o Executivo e, em última análise, para o próprio fenômeno da instabilidade no período examinado. 
Mais especificamente, a introdução das regras "distritais", ao alterar a circunscrição onde se dava a competição eleitoral, propiciou mais autonomia às bases do sistema (eleitorado de $2^{\circ}$ grau e chefias locais), hábeis a partir de então a lançar candidatos competitivos nos pleitos ao Legislativo, abrindo-se efetiva oportunidade para a eleição de representantes menos dependentes em face das elites provinciais e nacionais, isto é, frente às direções partidárias. Isso dificultou, em um contexto de processo decisório legislativo relativamente descentralizado, o controle da Câmara pelos gabinetes, intensificou as relações conflituosas entre os poderes Executivo e Legislativo e conduziu a impasses que, frequentemente, redundaram na retirada de gabinetes por pressão parlamentar.

Várias evidências, diretas e indiretas, são arroladas para sustentar o argumento, destacando-se:

1) Convergência das fontes e da literatura em enfatizar as consequências da mudança de regime eleitoral, sem conectá-las, no entanto, ao fenômeno da instabilidade governamental do Segundo Reinado;

2) O menor mandato médio dos gabinetes que governaram frente a legislaturas "distritalizadas" quando comparado ao tempo de exercício dos ministérios que se relacionaram com Câmaras escolhidas pelas listas;

3) A associação entre a queda de gabinetes por pressão do Legislativo e a vigência de regras eleitorais "distritalizadas";

4) A diferença das relações entre gabinetes e Câmara na $9^{\mathrm{a}}$ e $10^{\mathrm{a}}$ legislaturas, a primeira eleita por listas e a segunda sob a regra dos círculos ("distritos"), verificando-se enfraquecimento, na passagem de uma para outra legislatura, quanto à capacidade do Executivo de aprovar sua agenda.

$\mathrm{O}$ artigo está organizado da seguinte forma. Inicialmente, apresentam-se os traços mais importantes do arranjo político-institucional vigente no Segundo Reinado e delineia-se a visão dominante sobre o seu funcionamento (seção II). Em seguida, desenvolve-se o argumento referente ao primeiro eixo de preocupações do texto (seção III). Examina-se a questão da instabilidade de gabinetes e são propostos padrões explicativos para as retiradas ministeriais, a partir de critérios que sublinham a eventual atuação da Coroa e/ou do Legislativo nesses episódios. Feito isso, investigam-se as 37 retiradas ministeriais que se processaram entre 1840 e 1889, especificando suas razões políticas e enquadrando-as em um dos padrões estipulados. Subsequentemente, são sumariados os resultados desse primeiro eixo investigativo, mostrando suas novidades e diferenças em relação às posições clássicas sobre o assunto (seção IV). A partir daí, foca-se o segundo eixo temático deste artigo, especificando e detalhando a hipótese que busca explicar as razões dos sistemáticos confrontos entre gabinetes e Câmaras. Lastreando o argumento, são expostos, com maior minúcia, os vários tipos de evidência, acima assinalados, que parecem sustentar a explicação aqui ventilada (seções V a VII). Uma seção de conclusão finaliza o trabalho.

\section{O Arranjo Institucional e sua Interpretação Clássica}

Após três décadas de conflitos, o Império alcançou, por volta de 1850, uma relativa estabilidade, estruturando-se, no território da antiga América Portuguesa, uma ordem política relativamente eficaz. Configurou-se um modelo institucional próximo à monarquia parlamentarista, assentado em um esquema bipartidário formado pelos Partidos Conservador e Liberal. O parlamentarismo, que não constava da Carta de 1824 nem do Ato Adicional (1834), foi se esboçando nos últimos anos da Regência e na década de 1840. 
${ }^{6}$ Ver artigos 101 e 62 a 68 da Constituição do Império (Brasil 1824).

${ }^{7}$ Entre as poucas exceções a essa visão figuram Pereira de Castro (2004) e Dolhnikoff (2005).
O sistema compreendia legislativo bicameral (Senado vitalício e Câmara de Deputados temporária) e Executivo monárquico, mas delegado a um gabinete liderado por um presidente de conselho, e um Judiciário cujos membros eram indicados, em quase todos os níveis, por aquele gabinete. $\mathrm{O}$ voto era exercido em um sistema de duplo grau (indireto) e a elegibilidade a cargos políticos dependia de critérios censitários. O sufrágio foi exercido regularmente, tendo sido eleitas, a partir de 1826, 21 legislaturas da Câmara dos Deputados nos quase 70 anos do regime.

A participação política - em termos da dimensão relativa da população apta a exercer, em algum grau, direitos políticos - alcançou níveis expressivos pelos padrões da época. Do contingente populacional total, livre e escravo, de qualquer idade e de ambos os sexos, $13 \%$ dos brasileiros, em 1872, estavam qualificados para votar (Graham 1997, p.418). Esses números não destoavam dos existentes, no período, no cenário europeu e norte-americano (Carvalho 2002, p.31; Lamounier 2005, pp.77-85). A restrição ao sufrágio, no Brasil imperial, decorreu da reforma eleitoral de 1881, que reduziu o direito do voto a menos de $1 \%$ da população, colocando o país na contramão da tendência no Ocidente à extensão de direitos.

A monarquia abrigou também um quarto poder, o Moderador, titularizado pelo imperador. Suas competências garantiam à Coroa supremacia sobre os demais poderes. A Constituição do Império entregava ao Moderador poderes para a nomeação e a demissão de ministros; a convocação extraordinária, prorrogação e adiamento da Assembleia Geral, composta de Senado e Câmara; a dissolução da Câmara; a suspensão de magistrados; o perdão de penas e a concessão de anistia. As prerrogativas incluíam ainda o veto sobre as decisões do Legislativo e a nomeação dos senadores, a partir de listas tríplices provinciais ${ }^{6}$.

Não causa surpresa, portanto, que os estudiosos tenham enfatizado o papel do imperador na dinâmica política do Segundo Reinado, considerado ator central e fiador do processo político da época. Munido das prerrogativas assinaladas, o Trono teria controle sobre o sistema, mantendo sob suas rédeas os gabinetes e regulando as alternâncias partidárias entre conservadores e liberais ${ }^{7}$.

Assim, para Sérgio Buarque de Holanda, era Pedro II que escolhia os gabinetes e estipulava as diretrizes de governo (Holanda 1985, pp.19-22). Francisco Iglésias sustenta que Pedro II reinou, governou e administrou (Iglésias 2004, p.113). O outro lado dessa moeda teria sido o caráter formal, nunca efetivo, das instituições representativas parlamentares (Iglésias 2004, pp.113-114). Raymundo Faoro concorda: o governo pessoal do imperador era realidade reconhecida (Faoro 2001, p.413). Era dele a escolha do partido que subia ao poder e a responsabilidade pela entrega a este dos meios de fazer a maioria legislativa. As funções da Câmara eram secundárias quando comparadas à força de que gozavam as instituições vitalícias, o Senado e o Conselho de Estado (Faoro 2001, p.396). Para esses autores, o parlamentarismo imperial funcionava às avessas por fluir de cima para baixo, como já denunciara à época o conselheiro Nabuco (1949, vol. III, p.110).

Brasilianistas como Needell e Barman convergem com a perspectiva esboçada. Needell (2006, p.6; p.200; 2009, pp.62-63) considera que durante o Segundo Reinado amplia-se a ação política de Pedro II. Na década de 1860, a Coroa abandonara a atitude de supervisão para evoluir rumo à condução das principais políticas dos ministérios - com consequências para a ordem social e para o desenvolvimento das instituições representativas. Barman (1988, p.238) salienta a centralidade do monarca e antecipa o seu protagonismo para a década de 1850: a essa altura o imperador já controlaria o sistema político. 
Limongi (2011, pp.2-4) salientou a avaliação positiva dos especialistas a respeito do exercício do Moderador por Pedro II. O uso adequado daquelas prerrogativas teria sido a base sobre a qual se estruturou sistema político estável, capaz de comportar a alternância pacífica de liberais e conservadores. Carvalho (2006, p.406) sintetiza essa posição: “[Na ausência do Moderador], ou o conflito seria extralegal ou seria suprimido por meio de arranjos de dominação como o que se desenvolveu na República Velha".

O esquema explicativo esboçado alcançou a Sociologia e a Ciência Política, as quais se pautaram pelas interpretações da historiografia.

Nos anos 1970, Fernando Henrique Cardoso, escrevendo sobre o início da República, assinalou que a questão-chave para o novo regime era definir quem faria às vezes do Moderador (Cardoso 1985, p.38). Renato Lessa, no limiar dos anos 1990, afirmou que a "Política dos Governadores", pactuada na República, significou "um equivalente funcional do Poder Moderador" (Lessa 1988, p.111). Perspectiva semelhante também aparece na contribuição de Backes (2006, pp.206-207) sobre a Primeira República. De modo mais explícito, mais recentemente, Wanderley Guilherme dos Santos sustenta que "era o imperador, em sua face absolutista de 'moderador', que fazia e desfazia gabinetes" (Santos 2013, pp.9-10).

Na linha das interpretações apresentadas, o Poder Moderador teria sido a peça central e o árbitro da dinâmica institucional do Império. Desaparecendo com a República, teria liberado o sistema político para convergir em direção ao equilíbrio da "ordem oligárquica", necessariamente local e regional (Limongi 2011).

\section{Instabilidade dos Gabinetes, Padrões de Retirada e a Análise dos Episódios}

\section{III.1. Instabilidade}

\footnotetext{
8 Figueiredo 1981, pp.149-151; Oliveira Vianna 1929, pp.39-40; pp.96-77; Holanda 1985, pp.9-10; pp.67-68; Holanda 2010, p.177; Fausto 2006, p.180; Carvalho 2006, pp.400-404; p.412.
}

III.2. Padrões
Para testar o esquema interpretativo clássico sobre o Segundo Reinado, explora-se uma característica desse arranjo enfatizada pelos estudiosos: $o$ contraste entre a estabilidade da monarquia e a alta rotatividade dos seus gabinetes (Holanda 1985, p.10, p.68; 2010, pp.176-177; Carvalho 2006, p.210). Entre 1840 e 1889, revezam-se 37 gabinetes, constatando-se permanência média no poder de pouco mais de um ano para cada ministério.

Embora destacando diferentes aspectos, os estudos existentes, produzidos a partir de cânones distintos, convergem quanto ao protagonismo da Coroa nas substituições ministeriais ${ }^{8}$.

No entanto, em que pese a impressionante convergência de diagnósticos, não há evidência empírica robusta sobre a matéria, uma vez que, praticamente, inexistem estudos que examinem cada uma das substituições ministeriais realizadas no período e avaliem suas razões do ponto de vista político, classificando-as de acordo com algum critério justificável, de modo a discernir padrões regulares. É essa lacuna que a primeira parte deste artigo busca suprir.

O critério classificatório aqui adotado para examinar as substituições de governo no Segundo Reinado foi a presença ou ausência de intervenção, nesse processo, da Coroa e/ou da Câmara dos Deputados. Isso fornece a seguinte estrutura de possibilidades, exposta, abaixo, na Figura 1.

Emergem, assim, quatro padrões, os quais são elucidativos dos motivos das rotações dos gabinetes. Os padrões são aqui detalhados: 
Figura 1 - Razões de substituição ministerial

\begin{tabular}{|c|c|}
\hline $\begin{array}{l}\text { Interferência da Coroa, } \\
\text { Interferência da Câmara } \\
\text { (Padrão 1) }\end{array}$ & $\begin{array}{l}\text { Interferência da Coroa, Não } \\
\text { Interferência da Câmara } \\
\text { (Padrão 2) }\end{array}$ \\
\hline $\begin{array}{l}\text { Não Interferência da Coroa, } \\
\text { Interferência da Câmara } \\
\text { (Padrão 3) }\end{array}$ & $\begin{array}{c}\text { Não Interferência da Coroa, Não } \\
\text { Interferência da Câmara } \\
\text { (Padrão 4) }\end{array}$ \\
\hline
\end{tabular}

Fonte: $\mathrm{O}$ autor.

Padrão 1. Interferência da Coroa, interferência da Câmara. Episódios em que as razões da substituição vinculam-se à perda pelo ministério de sustentação junto à Câmara e ao Trono, concorrendo ambos para a dissolução.

Padrão 2. Interferência da Coroa, não Interferência da Câmara. Mudanças em que o papel da Coroa é central. Essas substituições são divididas em três variantes, em função do tipo de interferência específica do Trono: (1) arbitragem em disputas intraministeriais; (2) divergências com presidentes de Conselho; (3) atuação na alteração de programas e/ou prioridades de governo.

Padrão 3. Não Interferência da Coroa, interferência da Câmara. Retiradas resultantes da perda de apoio, efetiva ou antecipada, dos incumbentes junto à Câmara ou, excepcionalmente, perante o Senado. Essas demissões se deflagram a partir de um dos seguintes fatos: (1) derrota do gabinete em questão de confiança; (2) resultado de votações que manifestam a precariedade da base parlamentar, seja em relação a proposições consideradas prioritárias, seja em disputas de cargos de direção na Mesa; (3) antecipação, quando o gabinete se retira por diagnosticar de antemão sua inviabilidade, consistindo, muitas vezes, em retiradas que ocorrem antes do início das sessões anuais do Legislativo, tendo havido ou não eleições.

Padrão 4. Não Interferência da Coroa, não Interferência da Câmara. Episódios em que a dissolução ocorre por decisão dos incumbentes, sem pressões ou interferências. Abrange casos residuais de dissolução por falecimento do chefe do ministério e por força do golpe republicano de 1889.

Em síntese, como retratado na figura 1 acima, os padrões 3 e 4 registram razões para a mudança não vinculadas ao Trono. Os padrões 1 e 2, ao contrário, estilizam situações de retirada imputáveis à atuação da Coroa. A interferência exclusiva da Câmara é retratada no padrão 3. A atuação exclusiva do Moderador é captada pelo padrão 2 .

III.3. Análise dos Episódios de Substituições de Gabinetes

Examinam-se agora os motivos políticos dos afastamentos de cada um dos ministérios, seguindo-se ordem cronológica. A Tabela 1 lista os gabinetes do Segundo Reinado, especificando coloração partidária, chefe do ministério e o seu início e fim.

Na sequência, agrupam-se os gabinetes em blocos, em função de linhas de continuidade e descontinuidade percebidas no transcurso da investigação realizada. 
Tabela 1 - Composição dos Gabinetes (1840/1889)

\begin{tabular}{|c|c|c|c|}
\hline Gabinete & Partido $^{\mathrm{I}}$ & Presidente ou Organizador do Gabinete & Início/Fim \\
\hline $1^{\circ}$ & L/GP & Antônio Carlos/Aureliano Coutinho & $24.07 .40-23.03 .41$ \\
\hline $2^{\circ}$ & $\mathrm{GP} / \mathrm{C}$ & Aureliano Coutinho & $23.03 .41-23.01 .43$ \\
\hline $3^{\circ}$ & $\mathrm{C}$ & Honório C. Leão & $23.01 .43-02.02 .44$ \\
\hline $4^{\circ}$ & L/GP & Almeida Torres (Macaé) & $02.02 .44-02.05 .46$ \\
\hline $5^{\circ}$ & $\mathrm{L}$ & Holanda Cavalcanti & $02.05 .46-22.05 .47$ \\
\hline $6^{\circ}$ & L/GP & Alves Branco & $22.05 .47-08.03 .48$ \\
\hline $7^{\circ}$ & $\mathrm{L}$ & Almeida Torres (Macaé) & $08.03 .48-31.05 .48$ \\
\hline $8^{\circ}$ & $\mathrm{L}$ & Paula Sousa & $31.05 .48-29.09 .48$ \\
\hline $9^{\circ}$ & $\mathrm{C}$ & Pedro Lima (Olinda) & $29.09 .48-06.10 .49$ \\
\hline $10^{\circ}$ & $\mathrm{C}$ & Costa Carvalho (Monte Alegre) & $06.10 .49-11.05 .52$ \\
\hline $11^{\circ}$ & $\mathrm{C}$ & Joaquim J. R. Torres & $11.05 .52-06.09 .53$ \\
\hline $12^{\circ}$ & C/Conc & Honório C. Leão (Paraná) & $06.09 .53-03.09 .56$ \\
\hline $13^{\circ}$ & C/Conc & Luís A. de Lima e Silva (Caxias) & $03.09 .56-04.05 .57$ \\
\hline $14^{\circ}$ & L/Conc & Pedro Lima (Olinda) & $04.05 .57-12.12 .58$ \\
\hline $15^{\circ}$ & $\mathrm{C} /$ Conc & Limpo de Abreu (Abaeté) & $12.12 .58-10.08 .59$ \\
\hline $16^{\circ}$ & C/Conc & Ângelo Ferraz (Uruguaiana) & $10.08 .59-02.03 .61$ \\
\hline $17^{\circ}$ & $\mathrm{C}$ & Luís A. de Lima e Silva (Caxias) & $02.03 .61-24.05 .62$ \\
\hline $18^{\circ}$ & LP & Zacarias Góis & $24.05 .62-30.05 .62$ \\
\hline $19^{\circ}$ & LP & Pedro Lima (Olinda) & $30.05 .62-15.01 .64$ \\
\hline $20^{\circ}$ & LP & Zacarias de Góis & $15.01 .64-31.08 .64$ \\
\hline $21^{\circ}$ & LP & Francisco Furtado & $31.08 .64-12.05 .65$ \\
\hline $22^{\circ}$ & LP & Pedro Lima (Olinda) & $12.05 .65-03.08 .66$ \\
\hline $23^{\circ}$ & LP & Zacarias Góis & $03.08 .66-16.07 .68$ \\
\hline $24^{\circ}$ & $\mathrm{C}$ & Joaquim J. R. Torres (Itaboraí) & 16.07.68 - 29.09.70 \\
\hline $25^{\circ}$ & $\mathrm{C}$ & Pimenta Bueno (São Vicente) & $29.09 .70-07.03 .71$ \\
\hline $26^{\circ}$ & $\mathrm{C}$ & José M. Paranhos (Rio Branco) & $07.03 .71-25.06 .75$ \\
\hline $27^{\circ}$ & $\mathrm{C}$ & Luís A. de Lima e Silva (Caxias) & $25.06 .75-05.01 .78$ \\
\hline $28^{\circ}$ & $\mathrm{L}$ & Cansanção de Sinimbu (Sinimbu) & $05.01 .78-28.03 .80$ \\
\hline $29^{\circ}$ & $\mathrm{L}$ & José A. Saraiva & $28.03 .80-21.01 .82$ \\
\hline $30^{\circ}$ & $\mathrm{L}$ & Martinho Campos & $21.01 .82-03.07 .82$ \\
\hline $31^{\circ}$ & $\mathrm{L}$ & João L. Paranaguá (Paranaguá) & $03.07 .82-24.05 .83$ \\
\hline $32^{\circ}$ & $\mathrm{L}$ & Lafaiete Pereira & $24.05 .83-06.06 .84$ \\
\hline $33^{\circ}$ & $\mathrm{L}$ & Manuel Dantas & $06.06 .84-06.05 .85$ \\
\hline $34^{\circ}$ & $\mathrm{L}$ & José A. Saraiva & $06.05 .85-20.08 .85$ \\
\hline $35^{\circ}$ & $\mathrm{C}$ & João Wanderley (Cotegipe) & $20.08 .85-10.03 .88$ \\
\hline $36^{\circ}$ & $\mathrm{C}$ & João Alfredo & $10.03 .88-07.06 .89$ \\
\hline $37^{\circ}$ & $\mathrm{L}$ & Afonso Celso (Ouro Preto) & $07.06 .89-15.11 .89$ \\
\hline
\end{tabular}

Fonte: O autor, a partir de Javari (1962, pp.77-249), Nabuco (1949, vol. IV, pp.205-217).

I Abreviaturas: GP (Grupo Palaciano); L (Liberal); C (Conservador); LP (Liga Progressista); Conc (Conciliação). 
III.3.1. O Início do Segundo Reinado (1840-1848). Palacianos, "Regressistas” e Liberais: do $1^{\circ}$ ao $8^{\circ}$ Gabinete

9 Anais da Câmara dos Deputados ACD 24.05.1841 pp.242-243; Pereira da Silva 2003, pp.65-70, pp.79-83, pp.96-97, p.166; Tavares de Lyra 1979, p.295; Barman 1988, pp.201-212; 1999, pp.76-77; Needell 2006, pp.83-95; Ferraz de Carvalho 1933, p.222.
Esse bloco inicial de experiências governamentais - que vai do ministério da "Maioridade", em julho de 1840, até o gabinete liberal de Paula Sousa, demissionário em setembro de 1848 - emerge em cenário fluido, onde as matrizes institucionais e as identidades partidárias que se afirmarão no Segundo Reinado estão em construção. Destaca-se a atuação do grupo palaciano, presente na maior parte dos arranjos ministeriais formados, em aliança tanto com os políticos "regressistas" como, noutras vezes, com os setores que consolidarão o Partido Liberal.

Dos oito gabinetes que governaram nesse período, quatro serão afastados pela Coroa $\left(1^{\circ}, 3^{\circ}, 4^{\circ}\right.$ e $\left.6^{\circ}\right)$, sendo a outra metade substituída por pressão da Câmara $\left(2^{\circ}, 5^{\circ}, 7^{\circ}\right.$ e $\left.8^{\circ}\right)$. Dos ministérios que caem por interferência real, dois deles - o gabinete da "maioridade" e o gabinete chefiado por Macaé entre 1844 e 1846 - são vítimas de disputas entre seus integrantes, arbitradas por Pedro II ${ }^{9}$. Os ministérios liderados por Honório Leão e por Alves Branco entregam seus postos após desentendimento entre seus chefes e o imperador (Barman 1988, p.222; 1999, pp.100-102; Needell 2006, pp.105-107; Pereira de Castro 2004, pp.591-592, p.606; Costa Porto 1985, pp.108-109). Os governos cujos desfechos são determinados pela ação política da Câmara sofrem censura $\left(7^{\circ}\right.$ gabinete), são derrotados em matéria considerada prioritária pelos incumbentes ( $8^{\circ}$, Paula Souza) ou, perdendo o controle do plenário da câmara baixa, decidem se antecipar a colisões mais sérias com o Legislativo optando pela dissolução ministerial - caso do $2^{\circ}$ e do $5^{\circ}$ gabinetes (ACD 01.01.1843, pp.49-50; 26.05.1848, p.156; 19.05.1848, pp.96-98; Pinho 1930, p.139; Costa Porto 1985, pp.109-111; Barman 1988, pp.212-216, pp.220-221, p.231; Iglésias 2004, pp.19-20; Needell 2006, p.102, pp.104-105, p.115; Pereira da Silva 2003, pp.111-131, pp.134-140; 2004, pp.586-588).

\section{III.3.2. A Volta dos "Saquaremas" (1848-1853): do $9^{\circ}$ ao $11^{\circ}$ Gabinete}

Após perder o poder quando da "Maioridade", e, novamente, em 1843, como resultado do choque entre Honório Leão e a Coroa, o "Regresso" retorna ao comando do Império durante o quinquênio 1848-1853. Trata-se de período em que - na esteira da repressão às revoltas liberais da década de 1840 e do fracasso desse agrupamento em sustentar governos estáveis - afirma-se, com vigor, o governo partidário conservador, à frente o célebre triunvirato "saquarema”, formado por Eusébio de Queiroz, Paulino de Sousa e Rodrigues Torres.

A mudança ministerial, em setembro de 1853, no final desse período, que entrega o poder a outro eminente líder conservador, Paraná, assinalaria, porém, o crepúsculo da dominância conservadora estrita no Império. Com exceção do gabinete Itaboraí no final da década de 1860, não se voltará a presenciar gabinetes "saquaremas" ortodoxos e, dentro do Partido Conservador, prevalecerão, como alternativa efetiva de poder, os políticos mais moderados e abertos ao diálogo com o imperador.

Das formações ministeriais desse período, duas $\left(9^{\mathrm{a}}\right.$ e $\left.11^{\mathrm{a}}\right)$ são substituídas por força de redirecionamento nas prioridades governamentais, o qual visava, respectivamente, uma nova linha de política externa no Rio da Prata e um esforço de composição de governos suprapartidários. Em ambos os casos o papel da Coroa foi decisivo nas trocas de comando no Executivo (Ferraz de Carvalho 1933, p.238; Nabuco 1949, vol. 1, pp.114-117, p. 160; Pereira da Silva 2003, p.244; Iglésias 2004, pp.23-24; Needell 2006, pp.121-123). O $10^{\circ}$ gabinete, por sua vez, sucumbiu a pressões conjuntas da Câmara e do Trono, mostrando-se incapaz de compatibilizar as exigências da Coroa - voltadas à limitação do 
caráter partidário do governo -com as crescentes demandas de patronagem do Partido Conservador na Câmara e nas províncias (Needell 2006, pp.137-138; 161-163; Iglésias 2004, pp.30-31; Pereira da Silva 2003, pp.239-240).

III.3.3. Incorporação e Ruptura. A “Conciliação” (1853-1857): 12 e $13^{\circ}$ Gabinetes

O gabinete Paraná $\left(12^{\circ}\right)$ é um marco no Segundo Reinado por romper - por meio da chamada "Política da Conciliação" - com o domínio exclusivo dos conservadores sobre a máquina político-administrativa. A partir dele se abrirá espaço para a incorporação, nos canais político-institucionais de representação e nos postos da administração pública, do Partido Liberal, no ostracismo desde o fim da década de 1840 .

As iniciativas da "Conciliação" influenciaram a evolução do Império. A divisão do Partido Conservador, a partir desse período, entre moderados e "puritanos", espelhando a adesão e a rejeição, respectivamente, à linha conciliatória, e a ulterior experiência da "Liga Progressista", nos anos 1860, são fenômenos políticos que encontram suas raízes nas decisões tomadas pelo gabinete Paraná.

Chefe de um dos mais fortes gabinetes do Segundo Reinado, Paraná foi surpreendido pela morte, que o atingiu no exercício do poder, quando figurava como o político mais influente do Império. O ministério que o sucedeu governou sob a égide da provisoriedade, ultimando providencias iniciadas e maturadas por Paraná - em especial, a reforma eleitoral de 1855. Em maio de 1857, concluída a execução da reforma eleitoral e ciente da falta de suporte na legislatura que se inaugurava, o $13^{\circ}$ ministério antecipou-se a eventuais dificuldades com a nova Câmara e entregou os postos (Nabuco 1949, vol. 1, pp.401-405; Costa Porto 1985, pp.155, pp.162-163; Iglésias 2004, pp.55, p.77; Needell 2006, p.194).

III.3.4. A Pós-Conciliação (1857-1861): do $14^{\circ}$ ao $16^{\circ}$ Gabinete

Esses gabinetes integram um período "pós-conciliação", no sentido de que essa bandeira suscitou, no intervalo em foco, substantivo apelo no meio político-parlamentar, exercendo influência na composição dos ministérios da época, sempre "mistos". No entanto, não se verifica, na dinâmica prática da política, a emergência de agendas consensuais ou capazes de carrear para os governos apoio legislativo confiável.

Ao contrário, esse intervalo assiste - superposta à "conciliação" e, em boa medida, corroendo-a - à cristalização de polarização de posições, no Legislativo e na sociedade, em torno de medidas monetário-financeiras, em especial no que concerne à política bancária e de crédito. Essas divisões reacendem rivalidades e engendram novas oposições, preparando o terreno para reformulações no quadro partidário a partir da década de 1860.

Vítimas da polarização de posições e de uma legislatura cindida ao meio $\left(10^{\mathrm{a}}\right)$, os três gabinetes desse período se retiram por incapazes de mobilizar maioria no Legislativo, tendo o Trono atuado também na retirada do $14^{\circ}$ gabinete (ACD maio/agosto 1858; Costa Porto 1985, pp.168-176; Holanda 1985, pp.22-23; 2010, pp.62-65; Pereira da Silva 2003, pp.261-274; Iglésias 2004, pp.79-88, pp.100-101; Needell 2006, p.205, pp.210-214).

III.3.5 De Caxias à “Liga Progressista” (1861-1868): Do $17^{\circ}$ ao $23^{\circ}$ Gabinete

Inicialmente, o gabinete Caxias $\left(17^{\circ}\right)$, ascendente na inauguração da $11^{\mathrm{a}}$ Legislatura (1861-3), procurou reunificar as alas do Partido Conservador, 
divididas desde o início da "Conciliação" e, subsequentemente, buscou governar a partir do núcleo ortodoxo do partido, alheando-se das forças que sustentavam o entendimento interpartidário iniciado em 1853 por Paraná. Essa guinada à direita não prosperou diante de uma Câmara dividida. Após o afastamento de Caxias, inicia-se, no período em foco, a dominância - relativamente longa, mas nunca estável - dos gabinetes "ligueiros", compostos pela aliança entre os adversários do $17^{\circ}$ gabinete: os conservadores dissidentes, herdeiros do legado de Paraná, e parcela dos liberais. Essa hegemonia da "Liga Progressista" se prolongará até julho de 1868, quando a intervenção do Moderador trará de volta os conservadores "puritanos".

A instabilidade do período - sete ministérios em sete anos - se relaciona à continuada tensão das relações entre governo e Câmara. Cinco dos sete gabinetes caem por falta de sustentação parlamentar, perdendo o $20^{\circ}$ gabinete também o apoio da Coroa. No interior desse conjunto, sucedem-se episódios de censura expressa $\left(17^{\circ}\right.$ e $18^{\circ}$ gabinetes), derrotas em votações consideradas estratégicas pelos incumbentes $\left(20^{\circ}\right.$ e $\left.21^{\circ}\right)$, bem como avaliações antecipadas de perda de controle do plenário $\left(19^{\circ}\right)^{10}$.

Somente um dos gabinetes desse intervalo - o $22^{\circ}$ - se afasta voluntariamente, sem interferências externas (Nabuco 1949, vol. 2, pp.345-246, pp.383-284, pp.389-294; Pereira da Silva 2003, pp.345-346, pp.359-361; c 1962, p.141; Iglésias 2004, p.124). O último dos gabinetes da "Liga", no entanto, o mais conhecido dentre os liderados por Zacarias de Góes $\left(23^{\circ}\right)$, é derrubado por decisão da Coroa, na mais traumática inversão partidária do Segundo Reinado ${ }^{11}$.

\section{III.3.6. Política, guerra e reformas sociais: o Gabinete Itaboraí e seus Limites: $24^{\circ}$ Gabinete (1868-1870)}

${ }^{10}$ ACD 28.05.1862, pp.100-103; Apêndice ACD 28.05.1862, pp.36-37; ACD, 8.05.1865, p.17; Santos 1930, p.85; Ferraz de Carvalho 1933 pp.253-254, pp.258-260; Nabuco 1949, vol. 2, pp.92-93, pp.96-97, p.147; Costa Porto 1985, pp.184, pp.187-189; Pereira da Silva 2003, pp.288-289, pp.291-292, p.307, pp.326-328, p.344; Iglésias 2004, pp.118-121; Needell 2006, pp.215-221, p.395, nota 11; Holanda 2010, pp.86-88.
A necessidade, avaliada pelo trono, de alinhar o comando militar e político do Império, como meio de acelerar o final do conflito bélico com o Paraguai, esteve na raiz da entrega da chefia ministerial ao visconde de Itaboraí, em julho de 1868. Essa inversão partidária, a mais célebre do período, de responsabilidade direta do Poder Moderador, encerrou o domínio da "Liga". Denunciado como "golpe de Estado", por "progressistas" e liberais, os apeados do poder na ocasião, esse episódio influenciará a reorganização partidária da década de 1870.

Mas a volta dos "saquaremas" não seria duradoura. Vencida a guerra, a prioridade às reformas do trabalho servil inviabilizou a continuidade dos conservadores ortodoxos no poder, uma vez que, para estes, tal programa era inaceitável. Desse modo, a substituição de Itaboraí ( $24^{\circ}$ gabinete) refletiu decisão da Coroa comprometida com políticas incompatíveis com os "saquaremas"12.

III.3.7. Pimenta Bueno, Rio Branco e Caxias, os conservadores do Imperador (1870-1878): do $25^{\circ}$ ao $27^{\circ}$

Gabinete

${ }^{11}$ Nabuco 1949, vol. 3, pp.91-104, pp.112-114; Pereira da Silva 2003, pp.370-383; Ferraz de Carvalho 1933, pp.264-269; Iglésias 2004, pp.128-139; Holanda 1985, pp.7-8, pp.105-108; 2010, pp.145-152, 159-60; Needell 2006, pp. $244-248$.
O domínio conservador irá até 1878 , adquirindo centralidade, no período, o gabinete Rio Branco, o mais longo do Segundo Reinado, responsável pela execução de reformas importantes. O traço comum desses ministérios é seu caráter não-"saquarema". Os seus chefes, embora conservadores, eram estranhos à ala "puritana" do partido da Ordem. Sua lealdade dirigia-se ao imperador.

Nesse período, a batalha travada por Rio Branco para aprovar a chamada "Lei do Ventre Livre" (setembro, 1871) dividirá, mais uma vez, o Partido Conservador - de modo análogo ao que ocorreu na década de 1850 durante o gabinete Paraná - sedimentando posições rivais na agremiação que persistirão até o fim da monarquia. 
12 Nabuco 1949, vol. 3, pp.147-159, pp.21-55; Pereira da Silva 2003, pp.409-415; Holanda 1985, pp.113-115, pp.119-127; Needell 2006, pp.254-266.

13 Nabuco 1949, vol. 3, pp.161-168, pp.177-181; Ferraz de Carvalho 1933, pp.280-281; Holanda 1985, pp.127-132, pp.135-136; Needell 2006, pp.266-271.
Os três gabinetes sairão por razões diversas: Pimenta Bueno $\left(25^{\circ}\right)$, convocado para aprovar as reformas no trabalho escravo, pedirá demissão por não controlar maioria no Legislativo para transformar as propostas em lei ${ }^{13}$. Rio Branco, chefe do ministério mais longo e bem-sucedido do Segundo Reinado $\left(26^{\circ}\right)$, renuncia por iniciativa própria, ausentes pressões da Coroa ou da Câmara, e faz o sucessor (Pereira da Silva 2003, p.447; Nabuco 1949, vol. 3, p.309; Holanda 1985, pp.172-173). O $27^{\circ}$ gabinete, liderado por Caxias, encerra seu mandato por força da decisão de Pedro II de mudar o regime eleitoral, convocando os liberais para realizar a reforma, uma vez que esse partido fora o primeiro a defender a ideia ${ }^{14}$.

\section{III.3.8. O "Segundo Quinquênio Liberal” (1878-1885): do $28^{\circ}$ ao $34^{\circ}$ Gabinete}

14 Nabuco 1949: vol. 3, pp.396-407; vol. 4, pp.89-99; Pereira da Silva 2003, pp.447-463; Ferraz de Carvalho 1933, pp.286-290; Holanda 1985, pp.173-189.

${ }^{15}$ ACD 30.06.1882, p.129; ACD 14.05.1883, pp.87-100; ACD 04.05.1885, pp.11-12; Pereira da Silva 2003, pp.506-508, pp.513-514, pp.527-542; Figueiredo 1898 , p.27, pp.32-34, p.119, pp.149-150; Santos 1930, pp.148-149.
Depois de uma década na oposição, voltam os liberais, em 1878, para introduzir reforma eleitoral ("eleições diretas" e censitárias), a qual reduziu a participação popular na representação vigente. Aprovada essa alteração institucional, o foco do período se deslocará para questões de equilíbrio fiscal e financeiro do Tesouro e, em especial, para a temática social, reemergindo as discussões sobre a extinção do trabalho escravo. Essas discussões transbordarão as fronteiras do mundo oficial e ganharão as ruas com a campanha abolicionista no decurso dos anos 1880 .

Aguda instabilidade caracteriza esse intervalo (1878-1885), revezando-se, no comando do Executivo, sete formações, seis das quais se retiram por falta de sustentação, efetiva ou antecipada, no Parlamento. Somente o $29^{\circ}$ gabinete se dissolve por iniciativa própria. Dos governos do período que sucumbem à pressão legislativa, três $\left(30^{\circ}, 31^{\circ}\right.$ e $33^{\circ}$ gabinetes $)$ são derrotados em moções de confiança ${ }^{15}$. Outro gabinete - o $32^{\circ}$, de Lafaiete Pereira - mesmo tendo êxito em duas votações prioritárias, avalia - pela margem mínima dos resultados carecer de condições estáveis de governança, optando também pela retirada ${ }^{16}$. O ministério chefiado por Sinimbu $\left(28^{\circ}\right)$ e a segunda experiência de Saraiva à frente do Conselho de Ministros $\left(34^{\circ}\right)$ são conduzidos à dissolução por anteciparem impotência frente à maioria conservadora no Senado, em um contexto onde projetos de lei prioritários necessitavam aprovação da casa vitalícia ${ }^{17}$.

\section{III.3.9. Cotegipe, João Alfredo e Ouro Preto: os últimos gabinetes ( $35^{\circ}$ ao $\left.37^{\circ}\right)$}

${ }^{16}$ ACD 03.06.1884, p.3; pp.5-7; pp.9-11; Pereira da Silva 2003, pp.526-527; Javari 1962, p.209, p.373; Ferraz de Carvalho 1933, pp.302-303.

${ }_{17}$ Pereira da Silva 2003, pp.461-476, pp.542-549; Ferraz de Carvalho 1933, pp.289-392, pp.308-310; Holanda 1985, pp.189-238; Leite 1978, pp.151-153; Figueiredo 1898, pp.36-40; Carvalho 2006, p.406; 2007, pp.186-187.
O movimento abolicionista - progressivamente vitorioso na sociedade funciona como um dos principais condicionantes da evolução dos derradeiros ministérios imperiais. A inversão partidária de 1885 - que eleva o Barão de Cotegipe, à presidência do Conselho, trazendo de volta o Partido Conservador, após sete anos na oposição - ocorre pela necessidade de completar, no Senado, de maioria conservadora, a tramitação de projeto relativo ao trabalho servil.

Entretanto, se a onda abolicionista - por vias oblíquas e, de certo modo, paradoxais - colabora para repor os velhos "ordeiros" no comando, é ela também, indiretamente, que provoca a inviabilização do gabinete Cotegipe, substituído por João Alfredo, um político igualmente conservador, mas, ao contrário do seu antecessor "emperrado", comprometido com a abolição imediata e sem indenização (Figueiredo 1898, pp.42-44; Ferraz de Carvalho 1933, pp.312-313; Barman 1999, pp.336-341). O final dessa última gestão se vincula a denúncias de corrupção. Minadas suas bases legislativas de apoio, o governo entregou os cargos, apesar da resistência da Coroa em aceitar a solução (Ferraz de Carvalho 1933, p.316; Holanda 1985, p.354; Barman 1999, p.349).

No crepúsculo da monarquia, a Coroa, impossibilitada de encontrar sucessor para João Alfredo nas hostes conservadoras - divididas entre frações que não se toleravam - realiza inversão partidária, nomeando o gabinete liberal de 
Ouro Preto, o último do Império, deposto junto com o regime (Barman 1999, p.350; Ferraz de Carvalho 1933, pp.316-317; Buarque de Holanda 1985, pp.354-355).

\section{Rotações ministeriais e a dinâmica do Império}

A Tabela 2 soma e distribui os episódios examinados por padrões de retirada, listando os gabinetes englobados em cada um dos tipos de afastamento. Os resultados são surpreendentes à luz das interpretações dominantes da dinâmica política do período.

A Tabela 2 indica que das 37 ocorrências de demissão de governos, 19 $(51,3 \%)$ estão associadas ao padrão 3 , resultando da interferência da Câmara dos Deputados. Em 10 oportunidades (27\%), as substituições enquadram-se no padrão 2, revelando a responsabilidade política da Coroa na mudança de governo. Em 5 episódios (13,5\%), a rotação de gabinetes reflete decisão dos presidentes de Conselho ou casos residuais (padrão 4). Por último, 3 alterações ministeriais $(8,1 \%)$ são fruto de pressão conjunta do Trono e da Câmara (padrão 1).

Os dados e as evidências autorizam conclusões que desafiam, de modo não trivial, as perspectivas predominantes entre os estudiosos quanto à interpretação da dinâmica política do período.

Em contraste frente àquelas visões, apresentadas no início deste artigo, as informações sistematizadas sugerem que a atuação do Trono, através do Moderador, não explica a rotação de governos entre 1840 e 1889. Distintamente, o estudo realizado mostra que conflitos, efetivos ou potenciais, entre o executivo e o legislativo, em especial a Câmara dos Deputados (padrão 3), foram o motivo mais frequente para a queda de gabinetes no Império, respondendo por mais da metade dos episódios examinados (19 em 37).

Somando esse primeiro conjunto de casos àqueles em que a Câmara e o Trono exerceram, conjuntamente, interferência fundamental para a demissão de ministérios (padrão 1), nota-se que em cerca de 60\% das retiradas (22 em 37) há atuação política decisiva do Legislativo.

Esses dados desmentem a suposição de irrelevância das instituições representativas no sistema político do Segundo Reinado. É importante observar que a Coroa, nos casos de conflito entre a Câmara e o gabinete, dispunha de poderes constitucionais para dissolver a casa temporária (art. 101, V, CI), arbitrando os impasses em favor dos incumbentes ministeriais. A pesquisa empreendida mostra que, sistematicamente, durante o Segundo Reinado, salvo três exceções $^{18}$, o imperador não se definiu por esse caminho, o que testemunha, do

Tabela 2 - Gabinetes e razões de retirada

\begin{tabular}{lll}
\hline Razões de Retirada & $\mathbf{N}^{\circ}$ de Gabinetes/Total de Gabinetes & \multicolumn{1}{l}{ Gabinetes } \\
\hline $\begin{array}{l}\text { Padrão 1 (Interferência da } \\
\text { Coroa, Interferência da Câmara) }\end{array}$ & $3 / 37(8,1 \%)$ & $10^{\circ}, 14^{\circ}$ e $20^{\circ}$ \\
$\begin{array}{l}\text { Padrão 2 (Interferência da Coroa, Não } \\
\text { Interferência da Câmara) }\end{array}$ & $1^{\circ}, 3^{\circ}, 4^{\circ}, 6^{\circ}, 9^{\circ}, 11^{\circ}, 23^{\circ}, 24^{\circ}, 27^{\circ}$ e $35^{\circ}$ \\
$\begin{array}{l}\text { Padrão 3 (Não Interferência da } \\
\text { Coroa, Interferência da Câmara) }\end{array}$ & $19 / 37(51,3 \%)$ & $2^{\circ}, 5^{\circ}, 7^{\circ}, 8^{\circ}, 13^{\circ}, 15^{\circ}, 16^{\circ}, 17^{\circ}, 18^{\circ}, 19^{\circ}$, \\
$\begin{array}{l}\text { Padrão 4 (Não Interferência da } \\
\text { Coroa, Não Interferência da Câmara) }\end{array}$ & $5 / 37(13,5 \%)$ & $21^{\circ}, 25^{\circ}, 28^{\circ}, 30^{\circ}, 31^{\circ}, 32^{\circ}, 33^{\circ}, 34^{\circ}$ e $36^{\circ}$ \\
\hline
\end{tabular}

Fonte: $\mathrm{O}$ autor. 
${ }^{18}$ De 18 legislaturas, 11 foram dissolvidas. A Coroa arbitrou a favor do $19^{\circ}, 26^{\circ} \mathrm{e}$ $33^{\circ}$ gabinetes, dissolvendo a $11^{\mathrm{a}}, 14^{\mathrm{a}}$ e $18^{\mathrm{a}}$ legislaturas, as 3 exceções. Uma dissolução se destinou a antecipar a reforma de $1881\left(17^{\mathrm{a}}\right)$. Sete aconteceram em decorrência de alternância partidária, com o novo chefe do Conselho obtendo da Coroa a dissolução da Câmara preexistente, adversa ao ministério em ascensão. próprio ponto de vista do titular do Moderador, o custo político substantivo de colidir com a Câmara e, consequentemente, o peso não trivial dessa representação no jogo político imperial.

Por seu turno, a avaliação clássica de que as substituições ministeriais decorreram de intervenções da Coroa é incapaz de dar conta do fenômeno examinado na medida em que a ação direta do imperador, embora relevante, apareceu apenas em 10 dos 37 episódios de sucessão, isto é, em $27 \%$ do total de retiradas (padrão 2).

Ainda que se incluam aqui as modificações de governo que se efetuaram por intervenção conjunta do Trono e da Câmara (padrão 1; 8,1\%), alcança-se somente $35 \%$ do total de eventos de retirada, uma proporção notavelmente inferior à aferida acima para a Câmara (60\%) lançando-se mão do mesmo critério.

Quanto às alternâncias partidárias - aspecto enfatizado na literatura como a dimensão positiva do Moderador, que teria tornado possível a regulação do conflito no período - o estudo dos 9 episódios de inversão no Segundo Reinado, listados na Tabela 3 , mostra que em apenas três ocasiões essa mudança se deveu à iniciativa independente da Coroa, agindo o trono, em todas as outras oportunidades, em resposta à prévia inviabilização da sustentação parlamentar do ministério demissionário.

Em síntese, a conclusão mais importante da primeira parte deste artigo é que não há possibilidade de compreender a dinâmica de substituição de governos no "parlamentarismo" do Segundo Reinado - nem tampouco as alternâncias partidárias então efetuadas - sem inserir com destaque na análise o papel do Legislativo imperial, em particular da Câmara dos Deputados. Nesse sentido, a análise aqui realizada revela uma fisionomia institucional do regime muito diversa daquela tradicionalmente retratada pelo saber consolidado.

Com isso, fica patenteada a necessidade de serem repensados substantivamente os esquemas interpretativos até hoje correntes sobre o período. Em que pese o inegável caráter elitista e restritivo da experiência de governo representativo no Brasil do século XIX - aspecto, aliás, como já visto acima, em que o país não destoava da Europa e dos EUA da época - sua "densidade" e complexidade institucional foram maiores do que imaginaram os estudiosos.

Seja por constituir o "locus" de enfrentamento e concertação das elites regionais e delas com a Corte, seja pelas prerrogativas que dispunha sobre o

Tabela 3 - Alternâncias partidárias nos Gabinetes (1840/1889)

\begin{tabular}{|c|c|}
\hline Substituição do gabinete com alternância ${ }^{I}$ & Padrões da Retirada \\
\hline $3^{\circ}(\mathrm{C})$ para $4^{\circ}$ (L/Grupo Palaciano), em 02/02/44 & 2 \\
\hline $8^{\circ}(\mathrm{L})$ para $9^{\circ}(\mathrm{C})$, em $29 / 09 / 48$ & 3 \\
\hline $13^{\circ}$ (C/Conc) para $14^{\circ}$ (L/Conc), em 04/05/57 & 3 \\
\hline $14^{\circ}(\mathrm{L} /$ Conc $)$ para $15^{\circ}(\mathrm{C} /$ Conc $)$, em $12 / 12 / 58$ & 1 \\
\hline $17^{\circ}(\mathrm{C})$ para $^{\circ}(\mathrm{LP})$, em 24/05/62 & 3 \\
\hline $23^{\circ}(\mathrm{LP})$ para $24^{\circ}(\mathrm{C})$, em $16 / 07 / 68$ & 2 \\
\hline $27^{\circ}(\mathrm{C})$ para $28^{\circ}(\mathrm{L})$, em $05 / 01 / 78$ & 2 \\
\hline $34^{\circ}(\mathrm{L})$ para $35^{\circ}(\mathrm{C})$, em $20 / 08 / 85$ & 3 \\
\hline $36^{\circ}(\mathrm{C})$ para $37^{\circ}(\mathrm{L})$, em $07 / 06 / 89$ & 3 \\
\hline
\end{tabular}

Fonte: $\mathrm{O}$ autor.

I Abreviaturas: L (Liberal); C (Conservador); LP (Liga Progressista); Conc (Conciliação). 
${ }^{19}$ Uma discussão sobre as características da Câmara dos Deputados no Império, bem como acerca de abordagens do tópico na literatura, pode ser encontrada em Ferraz (2012, pp.212-228). orçamento público, ou ainda por condensar institucionalmente toda uma estrutura de compromissos e reciprocidades que percorria de alto a baixo o Império ${ }^{19}$, o fato é que a Câmara - e, certamente também o Senado, outro território aguardando pesquisadores - desempenhou um papel muito mais relevante no Segundo Reinado do que até hoje se reconheceu, sugerindo a existência, no sistema político da época, de uma teia ativa de interesses de dimensões bem superiores ao que comumente se pressupôs, a ser tida em consideração e processada como condição de reprodução do arranjo de poder. Como se mostrou, não foi sem tensão e recorrentes conflitos essa reprodução. A investigação dos motivos subjacentes aos conflitos entre governos e o Parlamento constitui o segundo eixo deste artigo, a ser enfrentado a partir da próxima seção.

\section{Relações Gabinete e Legislativo: argumento e evidências}

A partir daqui o trabalho se volta para o seu segundo eixo de preocupações, dedicado à investigação do padrão mais frequente associado à instabilidade ministerial, a saber, as relações, marcadas por recorrentes conflitos, entre os gabinetes e a Câmara de Deputados. A meta é contribuir para a compreensão das razões desses reiterados confrontos.

O argumento central é que a transição de sistemas eleitorais (das listas para o "distrito"), a partir de meados da década de 1850, fornece uma chave importante para a compreensão da natureza das relações Executivo-Legislativo no Segundo Reinado, estando na raiz do incremento do conflito entre os dois poderes. A nova regra eleitoral viria se somar a características institucionais "centrífugas" preexistentes do sistema de governo e do funcionamento interno da Câmara, acentuando a dimensão fragmentada do sistema político da época ${ }^{20}$.

Preliminarmente ao detalhamento da hipótese e ao arrolamento de evidências que a lastreiam, apresenta-se um esboço da legislação eleitoral do Império.

\section{As regras eleitorais no Império}

${ }^{20}$ Havia dependência dupla do gabinete, frente à Coroa e maiorias, cabendo-lhe manter a confiança junto às duas instâncias. As regras do trabalho legislativo exigiam do gabinete, para aprovar medidas, a reiterada arregimentação de maiorias, inexistindo "atalhos" centralizadores (prerrogativas legislativas exclusivas do Executivo, centralização de direitos parlamentares na Mesa ou em líderes etc.).

${ }^{21}$ Constituição do Império (Brasil 1824).
$\mathrm{Na}$ vigência da ordem imperial, o voto, exercido em um sistema de duplo grau, e a elegibilidade a cargos políticos dependiam de critérios censitários, nos termos dos artigos 45, IV e 90 a 95 da $\mathrm{CI}^{21}$. O sistema de duplo grau dividia o corpo eleitoral em votantes e eleitores.

Os primeiros, os votantes, participantes das eleições primárias (ou de $1^{\circ}$ grau), escolhiam os segundos, os eleitores, os quais sufragavam, no pleito de $2^{\circ}$ grau, os candidatos aos postos de deputados gerais, senadores e deputados provinciais. Existiam exigências constitucionais crescentes de renda mínima para que alguém se habilitasse como votante (art. 92, V), eleitor (art. 94, I), bem como para que pudesse concorrer à Câmara (art. 94, I) e ao Senado (45, IV). A Constituição adotava hipóteses adicionais de exclusão tanto para o exercício do voto, em ambos os graus (arts. 92 e 94), como para a elegibilidade aos cargos representativos (art. 95, II e III; art. 45, I a III). O artigo 97 da CI estabelecia que uma lei regulamentar determinaria “o modo prático das eleições”. Entre 1822 e 1889, sete diferentes normatizações, todas baseadas em fórmulas eleitorais majoritárias, organizaram os pleitos do Império.

A legislação promulgada entre 1822 e 1855 - compreensiva das Instruções de 26.03.1824, das de 04.05.1842 e da Lei n 387, de 19.08.1846 - instituiu um "majoritarismo provincial". Vigorava um sistema de lista completa, onde o eleitor tinha tantas opções quantas fossem as vagas existentes para a unidade provincial no Legislativo. Eram eleitos para a Câmara os candidatos mais sufragados na província. Esse regime eleitoral tinha caráter não paroquialista. Por funcionarem os distritos provinciais como "grandes Senados", as lideranças 
mais salientes eram privilegiadas politicamente, uma vez que se exigia, para o êxito nesse tipo de pleito, cacife eleitoral territorialmente distribuído.

O sistema de "chapas" foi substituído pela primeira Lei dos Círculos, de 1855 (Decreto $n^{\circ}$ 842, de 19.09.1855). De curta vida (só regulará uma eleição), baseava-se no sistema majoritário uninominal, numa inflexão favorável aos interesses das lideranças periféricas ao centro do sistema, em detrimento das elites nacionais e provinciais, em um esforço de abrir espaço à representação das minorias (Carvalho 2006, p.398; Needell 2006, pp.184-185). Segundo Nicolau, com o novo sistema, "as províncias foram divididas em distritos eleitorais (chamados 'círculos eleitorais'), cada um deles elegendo um deputado. Os eleitores das diversas paróquias que compunham o distrito se reuniam [...] para fazer sua escolha (eles agora votavam em um único nome). Um candidato necessitava [...] maioria absoluta dos votos para ser eleito" (Nicolau 2012, p.35), havendo previsão de rodadas eleitorais sucessivas na hipótese de não ser alcançada a maioria requerida.

Em 1860, um compromisso entre saliência e liderança local é fixado por meio da segunda Lei dos Círculos (Lei n ${ }^{\circ}$ 1082, de 18.08.1860), estipulando-se distritos de 3 deputados, sendo as circunscrições eleitorais (os "círculos") ampliadas e considerando-se eleitos os três candidatos mais votados (Nabuco 1949, vol. 1, p.216; Iglésias 2004, pp.98-99; Carvalho 2006, pp.399-400; Nicolau 2012, p.36). Recupera-se espaço para as elites partidárias sem que se retorne ao predomínio das listas.

Em 1875 volta a chapa completa por província, mas com voto limitado, através da "Lei do Terço" (Lei n 2675, de 20.10.1875), na perspectiva de preservar espaços para as minorias (Carvalho 2006, pp.399-400; Faoro 2001, p. 428). Essa legislação demarcou a única interrupção, após 1855, da utilização de sistemas eleitorais “distritalizados” no Segundo Reinado.

A introdução das “eleições diretas", no início da década de 1880, via Lei Saraiva, marcaria, por fim, o retorno às fórmulas majoritárias uninominais ("distritalizadas"), com maioria absoluta. Sob essa regra se elegeram os parlamentares das últimas quatro legislaturas do Império.

O Quadro 1, extraído de Nicolau (2012, p.40), com alterações ${ }^{22}$, sintetiza a evolução esboçada.

\section{O núcleo do argumento: listas, círculos, incentivos e suas consequências políticas}

${ }^{22}$ A alteração está na terceira coluna da segunda linha do Quadro 1. Nicolau (2012) diz que, no regime de 1855 , a especificação da quantidade de nomes que o eleitor (de $2^{\circ}$ grau) poderia sufragar era feita para o segundo e o terceiro turno, quando o eleitor votaria em um único nome. $\mathrm{Na}$ verdade, já no primeiro turno o eleitor sufragaria só um candidato (art. $1^{\circ}, \S 10^{\circ}$, do Decreto 842, de 19.09.1855).
Consoante assinalado, entre 1822 e 1855 vigorava a lista completa, onde o eleitor tinha tantas opções quantas fossem as vagas na Câmara dos Deputados existentes por províncias. Eram eleitos os candidatos que obtivessem, computados os sufrágios da província, o maior número de votos, até se preencher o número de vagas reservado àquela unidade geográfica do Império.

Desde cedo, na história eleitoral do país, essa lista de eleitos resultou menos da agregação de preferências individuais dispersas, por cada colégio eleitoral, do que da aquiescência do eleitorado a um rol previamente elaborado de nomes sancionados pelas elites políticas dominantes: esse rol era a "chapa".

Needell (2006, p.176) localiza já na década de 1830 essa prática e enfatiza o protagonismo das lideranças partidárias da Corte (Rio de Janeiro) na confecção e negociação das chapas. Barman (1988, p.220, p.223, p.301, nota 20), examinando as eleições para a Câmara dos Deputados na década de 1840, atesta a disseminação e a eficácia do mecanismo, transformado em peça central na dinâmica eleitoral do Império 
Quadro 1 - Sistemas eleitorais e eleições para a Câmara (1824-1889)

\begin{tabular}{|c|c|c|c|}
\hline Início da vigência & $\begin{array}{l}\text { Circunscrição Eleitoral (unidade } \\
\text { na qual o eleitor podia escolher } \\
\text { os seus deputados) }\end{array}$ & $\begin{array}{l}\text { Quantidade de nomes em que } \\
\text { o eleitor podia votar }\end{array}$ & Sistema Eleitoral \\
\hline $1824^{\mathrm{I}}$ & Província & $\begin{array}{l}\text { Tantas quantas fossem as } \\
\text { cadeiras da província na Câmara } \\
\text { dos Deputados }\end{array}$ & $\begin{array}{l}\text { Maioria simples: os mais } \\
\text { votados da província eram } \\
\text { eleitos. }\end{array}$ \\
\hline 1855 & Distrito de um representante & Um nome & $\begin{array}{l}\text { Maioria Absoluta: se nenhum } \\
\text { candidato obtivesse mais de } \\
50 \% \text { dos votos, era realizada } \\
\text { uma nova eleição entre os } \\
\text { quatro mais votados; se nenhum } \\
\text { obtivesse maioria absoluta, era } \\
\text { realizado um novo pleito com os } \\
\text { dois mais votados. }\end{array}$ \\
\hline 1860 & Distrito de três representantes & Três nomes & $\begin{array}{l}\text { Maioria simples: os três mais } \\
\text { votados no distrito eram eleitos. }\end{array}$ \\
\hline 1875 & Província & $\begin{array}{l}\text { Dois terços do número de } \\
\text { representantes na Câmara }\end{array}$ & $\begin{array}{l}\text { Maioria simples: os mais } \\
\text { votados da província eram } \\
\text { eleitos. }\end{array}$ \\
\hline 1881 & Distrito de um representante & Um nome & $\begin{array}{l}\text { Maioria absoluta: se nenhum } \\
\text { candidato obtivesse mais de } \\
50 \% \text { dos votos, era realizada } \\
\text { uma nova eleição entre os dois } \\
\text { mais votados. }\end{array}$ \\
\hline
\end{tabular}

Fonte: O autor, a partir de Nicolau (2012, p.40).

${ }^{\mathrm{I}} \mathrm{O}$ sistema eleitoral inaugurado em 1824 sofreu alterações em 1842 e 1846.

23 "Elaborar uma chapa não era [...] simples. [...] requeria engenhosidade e um conhecimento considerável. $[\ldots]$ as chapas eram [...] o produto de manobras complexas envolvendo os líderes políticos provinciais, o presidente e os ministros e políticos no Rio. A chapa iria permanecer como o elemento chave da nova organização da política" (Barman 1988, p.301, nota 20$)$.

${ }^{24}$ Relato elucidativo sobre a montagem de uma "chapa" para a Câmara, no contexto da política baiana, é oferecido por Pinho (1937, p.238, nota 1).

${ }^{25}$ Para Souza, o uso das listas eliminava a influência do eleitorado de cada paróquia: "[No regime eleitoral prévio aos círculos, os eleitores de $2^{\circ}$ grau] eram obrigados a votar nas chapas que os chefes, diretores centrais do partido, lhes remetiam, ou teriam de ver seus votos perdidos em
A elaboração de chapas - específicas para cada província e para cada pleito, em função dos diversos interesses a serem concertados, representados pelos nomes nelas incluídos - não era empreitada banal. Era substantiva a complexidade envolvida e a engenhosidade requerida na montagem da chapa "oficial", produto de trabalhosas negociações envolvendo líderes locais e provinciais, presidentes de província e membros do gabinete ${ }^{23}$.

O êxito dos nomes em uma lista dependia da adequada "calibragem" da chapa, em termos de interesses e nomes privilegiados, apta a equilibrar as pretensões das influências da Corte e das elites provinciais, mas também hábil a garantir a mobilização dos chefes locais nas diversas regiões de uma província. Se o grau de influência das diversas elites era assimétrico na montagem das chapas, com o Rio e as províncias preponderando frente às lideranças paroquiais, por outro lado, não se estaria, à primeira vista, em face de um mecanismo que traduziria imposição de alto a baixo ${ }^{24}$.

Fontes como Souza ${ }^{25}$ e Pereira da Silva ${ }^{26}$, no entanto, ultrapassam a constatação de uma simples "assimetria" e enfatizam que a regra das "chapas" inferiorizava cabalmente o eleitorado de $2^{\circ}$ grau e as chefias locais frente às elites centrais e provinciais.

De todo modo, à luz da pesquisa acadêmica e das fontes, o que fica realçada é a inocuidade, ou o alto risco, no sistema de chapas, do ponto de vista do eleitorado de $2^{\circ}$ grau, de divergir da oferta de candidatos previamente elaborada pelas direções. De uma parte, aventurar outros nomes seria manobra fadada ao fracasso, dada a relativa incapacidade dos chefes locais de articular apoios cruzados em uma circunscrição geográfica relativamente extensa (a província); de outra, negar o sufrágio aos nomes "oficiais" seria um convite a futuras represálias ${ }^{27}$. Enfraquecidos na barganha como decorrência dos incentivos 
candidaturas isoladas, destituídas de probabilidade de sucesso" (Souza 1979, p.79).

26 Dizia o deputado Pereira da

Silva (RJ): "Há uma província que dá 8 deputados, os partidos e o governo escrevem nela 4 ou 5 nomes [...], e incluem 3 ou 4 nomes que ninguém conhece, 3 ou 4 afilhados felizes. A província vota, porque nenhum município tem coragem de negar o voto sabendo que a sua votação não pode influir na eleição geral" (ACD 28.08.1855, p.263)

${ }^{27}$ Discutindo as listas, o deputado Mendes de Almeida mostra que estas, pressupondo ampla coordenação viabilizadora de apoios cruzados em uma circunscrição geográfica relativamente extensa, só podiam ser operadas eficazmente pelos partidos e pela administração, central e provincial (ACD 30.08.1855, pp.326-327)

${ }_{28}$ Em 1855, o deputado

Eduardo França fala em "chapas impostas", modo usual de fazer as eleições nas províncias, e pede reformas.

Meses depois, afirma: "a atual lei de eleições [Lei ${ }^{\circ}$ 387, de 19.08.1846] não dá [...] garantia para uma escolha livre; o povo não pode mais sofrer imposições de listas de designados" (ACD 02.06.1855, pp.40-42; 25.08.1855, p.229).

${ }^{29}$ Segundo Needell, um político típico do regime eleitoral pré-1855 tinha como um dos seus propósitos centrais "buscar impressionar as lideranças da elite partidária no Rio" (Needell 2006, p.185).

30 "Nesse regime, a candidatura desamparada pelos chefes de partido não tinha probabilidade de vingar. Dificilmente, um homem não filiado a um dos partidos, [...] conseguia ser eleito. Organizadas as listas dos candidatos $[\ldots]$ pelos $[\ldots]$ partidos, os eleitores não votavam em candidatos divergentes, pelo receio de fazer triunfar os adversários com a dispersão dos votos" (Souza 1979, p.80). embutidos nas leis eleitorais, não restava às lideranças locais outro caminho senão aquiescer à vontade das influências centrais.

Como as listas já lhes chegavam prontas, por cálculos feitos na Corte e no centro das províncias, era mais racional, do ponto de vista dos eleitores de segundo grau, sancioná-las, emprestando-lhes seus votos, o que lhes daria cacife para futuros pleitos junto aos governantes. A alternativa, inferior, seria arriscar seus sufrágios em candidaturas isoladas, condenadas de antemão ao fracasso, pela impossibilidade de seus parcos votos alterarem o somatório provincial $^{28}$.

Se, do ponto de vista dos eleitores e das chefias locais, a prática das chapas representava enorme redução de sua margem de manobra, para os políticos que aspiravam a um mandato a inclusão na "lista de designados", nos termos do deputado Eduardo França (ACD 25.08.1855, p.229), era passo crucial, sem o qual a entrada ou a permanência nas casas legislativas do Império seria, praticamente, impossível.

A fim de alcançar tal propósito, manter boas relações com os encarregados da preparação das chapas - as elites partidárias do Rio e dos centros de cada província ${ }^{29}$ - era para um pretendente a mandato ou um político já tarimbado uma meta de alta prioridade, a ser cultivada com máximo empenho ${ }^{30}$.

Implicação importante, do ponto de vista do sistema político, dessa dependência dos políticos profissionais - titulares de mandatos, e dos aspirantes a essa condição - em face das direções partidárias era o controle destas últimas sobre as bancadas, o que associava, em última análise, o regime das chapas a um padrão de disciplina no comportamento legislativo.

Eleger-se e reeleger-se era função, no regime das listas, menos da atenção às demandas específicas de uma constituency do que da manutenção de relações com as elites das agremiações. Cultivá-las, garantindo a renovação do mandato e a progressão na carreira - com acesso a postos disputados como presidências provinciais, posições em ministérios, cacife para realizar indicações e formar redes de clientela, etc. - dependia, entre outras coisas, de uma atuação consonante com as diretrizes das cúpulas partidárias e com os desígnios do gabinete.

O arranjo eleitoral pré-círculos configurava, assim, um sistema de incentivos favorecedor do controle, a partir de cima, das representações, do que decorria, como padrão mais frequente de comportamento parlamentar, a atuação disciplinada dos deputados frente às orientações partidárias.

O regime dos "círculos" alterou essa situação. As novas regras eleitorais modificaram a distribuição de poder entre elites centrais, provinciais e locais, com ganhos relativos para estas últimas, e transformaram as condições para a entrada e permanência no mercado político-eleitoral. A razão desse turning-point foi a previsão legal de redimensionamento da circunscrição eleitoral, que deixou, a partir de 1855 , de ser a província e passou a ser o "círculo", constituído por um grupo de municípios.

A competição por vagas no Legislativo deixou de acontecer na província como um todo e migrou para espaço territorial restrito. Tal inovação privou as elites centrais e provinciais das mencionadas vantagens de seu poder de coordenação, vitais numa eleição em que se coletavam votos por toda a província. A nova dimensão espacial mais limitada do "distrito" viabilizou a entrada, no mercado político-eleitoral, de lideranças locais, ou de seus protegidos, potencialmente hábeis, a partir das mudanças em foco, a amealhar votos suficientes à conquista de cadeiras na Câmara dos Deputados.

É útil recordar que a legislação da época não exigia registro prévio de candidaturas nem determinava controle das direções partidárias sobre esse 
processo. No que tange à autoridade sobre a determinação do rol de candidatos, a força das elites centrais e provinciais dependia, essencialmente, do tamanho da circunscrição estipulado em lei. Ao diminuir esse tamanho - inicialmente, de forma mais radical, em 1855 (círculo de 1 representante), posteriormente, de modo mais moderado (distritos de 3 representantes), a partir de 1860 - as reformas mexeram na característica institucional das regras eleitorais que embasava a supremacia das direções partidárias frente às lideranças locais.

Com isso, modificaram-se também os incentivos balizadores da atuação dos deputados e/ou dos aspirantes a essa condição. Se, à época das "chapas", o aval das direções era condição essencial para a entrada e a permanência na política partidária profissional, após 1855 passou a ser decisivo o prestígio eleitoral junto a uma constituency específica (o círculo por onde concorria o parlamentar ou seus desafiantes). Levar realizações para o grupo de municípios de seu "distrito" veio a constituir, a partir das reformas, o eixo de atuação de um parlamentar típico, o que aumentava a demanda parlamentar por patronagem junto ao gabinete e condicionava o comportamento do deputado na Câmara à sua avaliação quanto ao grau de atendimento, pelos incumbentes, de suas reivindicações.

Em síntese, o arranjo dos círculos engendrou incentivos que condicionava a disciplina parlamentar, frente às diretrizes do Executivo, à percepção, pelos próprios deputados, do grau de atendimento, por parte do ministério, às suas demandas por obras, serviços e patronagem junto às respectivas bases eleitorais. Essa nova realidade introduziu uma dimensão de incerteza quanto à capacidade dos governos de controlar o plenário da Câmara. Dado o grau de fragmentação das demandas parlamentares (associado, em certa medida, ao próprio desenho legal das constituencies), a ausência de mecanismos partidários internos de coordenação e a estrutura descentralizada dos trabalhos legislativos, a hipótese desta pesquisa associa o sistema eleitoral dos "círculos" a um enfraquecimento na disciplina parlamentar na Câmara e, por conseguinte, a um incremento na dificuldade dos gabinetes de angariar apoio legislativo estável.

Assim, o fim das "chapas" transformou a lógica da competição e redesenhou os incentivos com as quais se defrontavam os agentes políticos, mudando o funcionamento interno da Câmara dos Deputados e as suas relações com o Executivo. Tais alterações nas relações entre esses poderes estiveram na base do fenômeno da instabilidade governamental que marca o período e que foi objeto da primeira parte deste texto.

A introdução das regras "distritais", ao redefinir a circunscrição da disputa, propiciou maior autonomia às bases do sistema (eleitorado de $2^{\circ}$ grau e chefias locais), capazes agora de apresentar candidatos competitivos ao Legislativo, o que favoreceu a eleição de representantes menos dependentes das elites provinciais e nacionais. Isso dificultou, em um contexto de processo decisório legislativo relativamente descentralizado, o controle da Câmara pelos gabinetes, intensificou as relações conflituosas entre os poderes Executivo e Legislativo, e conduziu a impasses que, frequentemente, redundaram nas retiradas de gabinetes por pressão parlamentar.

A seguir, apresentam-se quatro grupos de evidências, diretas e indiretas, que corroboram a hipótese do segundo eixo deste artigo.

VII.1. Fontes, literatura e a mudança de regime eleitoral

É notável nas fontes da época, nos trabalhos ensaísticos e na literatura acadêmica, a convergência sobre os efeitos, em termos de alterações nos incentivos do jogo político-partidário, advindos da transição das listas para os 
"distritos". Não se faz relação, no entanto, entre esse ponto e o fenômeno mais geral da instabilidade ministerial do Segundo Reinado.

A fragilização da disciplina e da coesão partidária, como resultado dos círculos, e a antecipação desses efeitos por destacados políticos da época, antes mesmo da entrada em vigor das medidas, são anotados por Nabuco (1949, vol. 1, p.216) e Pereira da Silva (2003, p.254). Escrevendo 15 anos após a aprovação da primeira Lei dos Círculos, Souza (1979, p. 80) confirmava aquelas previsões, salientando o enfraquecimento e a fragmentação dos partidos em decorrência das alterações na legislação eleitoral a partir da década de 1850.

Comentando a transição, Iglesias (2004, pp.68-69) e Costa Porto (1985, p.158) oferecem uma visão expressiva do que estava em jogo e dos perfis políticos diversos associados a cada um dos arranjos eleitorais, um em declínio, outro em ascensão. O capital político decisivo para o êxito nos pleitos passava a ser o prestígio nas localidades e não mais as boas graças junto aos ministros e aos presidentes de província. A imposição de nomes pelas cúpulas cedia lugar a uma competição entre lideranças locais. Os efeitos "centrífugos" da introdução dos círculos - favorecendo as lideranças periféricas, enfraquecendo a mediação dos chefes provinciais/nacionais e abrindo fissuras na centralização do império - são destacados também por Faoro (2001, pp.425-426), Carvalho (2006, pp.398-399) e Needell (2006, p.185).

Exame dos Anais da Câmara revela as avaliações feitas, no calor da hora, acerca das consequências da "distritalização", por políticos que seriam afetados pelas mudanças. Destacam-se aqui pronunciamentos de três parlamentares, realizados em 1855 e em 1856, logo antes da entrada em vigor dos círculos, os quais interpretam as alterações nas regras, com diferentes argumentos, em linhas consonantes com a hipótese sustentada.

O primeiro deles vem a ser Benevenuto Taques. Favorável à reforma, ele assim se pronunciou, comparando círculos e listas: “[...] [com o projeto] as influências locais terão mais livres a intervenção que lhes cabe na eleição, sem que sejam dominadas pelas imposições das capitais e do governo. [...] o governo não pode impor aos distritos eleitorais candidatos estranhos a sua afeição". Taques previa que o projeto traria maior independência à Câmara porque incrementaria a autonomia dos representantes em face do governo e das influências provinciais (ACD, 29.08.1855, pp.287-288).

Por sua vez, os deputados Martin Francisco e Avelar Brotero contrastam os regimes das listas e dos "círculos" em termos de um raciocínio que articula tamanho da circunscrição, grau de risco e dimensão do incentivo à interferência oficial nos pleitos eleitorais. É, portanto, o comportamento do governo nas eleições, visto como variável em função de incentivos decorrentes das regras legais, que está em foco (ACD, 31.05.1856, pp.107-115).

\section{Diz Martin Francisco:}

“[em vista da aprovação da primeira Lei dos Círculos, não tem mais] [...] o governo a necessidade de lutar para não ser derrotado em uma província inteira, porque, senhores, quando o círculo de eleições era mais vasto, a derrota era para o governo de efeitos mais funestos: quando o governo não podia contar com um triunfo certo, lançava mão de todos os meios para não ser derrotado; agora porém que esses círculos se circunscreveram, agora que se o pensamento do governo não puder legalmente vencer em uma parte vencerá em outra, é de esperar que o voto seja mais sincero, porque o governo não tem motivos de intervir diretamente na eleição para se poupar a vergonha de uma derrota em uma província inteira" (ACD 31.05.1856, p.115).

Em outras palavras, o que os deputados afirmavam, e o que o trecho acima sintetiza, era que os círculos poupavam o governo de defrontar-se com uma 
situação próxima a um jogo em que o vencedor das eleições leva tudo (winner takes all), pela qual só existiriam duas alternativas como resultado de uma eleição provincial legislativa: a vitória ou a derrota, completas, do poder incumbente. Ambos enfatizavam que a nova lei, por tirar o governo do dilema de ganhar ou perder tudo, ensejava a chance de eleição de representação mais diversificada e fiel aos interesses presentes na sociedade.

No trecho transcrito encontram-se também pistas para se imaginar, com mais concretude, aspectos dos mecanismos através dos quais eram eventualmente geradas as chamadas câmaras unânimes nas eleições. Nesse sentido, o que os deputados visualizavam, ao comparar os dois momentos demarcados pela aprovação da nova lei, pode ser traduzido da seguinte forma. Em um contexto de informação escassa, a circunscrição do distrito ao círculo, em vez do distrito abarcar a província inteira, acarretava diminuição da incerteza sobre o equilíbrio das forças em competição, uma vez que, agora, com a nova regra "distritalizada", esse cálculo passava a ser feito para cada círculo e não para toda província. Para o governo, as eleições deixavam de se assemelhar a um único jogo, caracterizado por baixa informação e risco alto, o que incentivava o uso da máquina, em doses, de preferência, cavalares, a fim de garantir a predominância da situação. Distintamente, a nova realidade eleitoral centrada em círculos abrangentes de áreas equivalentes a alguns municípios (à época, freguesias) circunvizinhos - poderia ser equiparada a uma dinâmica baseada em vários jogos simultâneos, com mais informação, o que permitia, em princípio, compatibilizar a conquista de resultados majoritários por uma facção com a representação efetiva da minoria (não por acaso, o objetivo de Paraná, idealizador da reforma).

Em síntese, o que esses dois últimos parlamentares anteciparam, diante da introdução dos "círculos", foi a possibilidade de representação oficial de correntes minoritárias ou oposicionistas no parlamento, um fato não trivial na realidade política da época.

Por fim, cabe assinalar a existência de extensa literatura (fontes, estudos clássicos e historiografia) que fornece inequívoca avaliação a respeito das características gerais das legislaturas posteriores à introdução dos "Círculos". Sua marca é a ênfase nas dificuldades encontradas pelos governos em suas relações com a Câmara dos Deputados ${ }^{31}$.

\section{VII.2. Mandato médio dos gabinetes e regra eleitoral que governou a formação das legislaturas}

${ }^{31}$ Sobre o ponto, ver Buarque de Holanda (1985, pp.22-23; pp.37-38; pp.147-151; p.171; 2010, pp.59-65; p.94); Pereira da Silva (2003, pp.265-275; pp.287-288; pp.510-550); Needell (2006, pp.200-202; pp.220-221); Carvalho (2006, pp.405-410); Nabuco (1949, vol III, pp.243-244); Faoro (2001, p.429).
Os gabinetes que governaram diante de legislaturas "distritalizadas" ficaram, em média, menos tempo no exercício de suas funções do que as formações governamentais que se relacionaram com câmaras eleitas pelo regime de listas. O tempo médio de permanência dos primeiros - gabinetes coexistentes com câmaras "distritais" - à frente das pastas do Executivo, foi $16 \%$ menor do que o tamanho do mandato médio das últimas - as equipes de governo que se relacionaram com corpos parlamentares eleitos por listas provinciais.

A Tabela 4 confronta o mandato médio de gabinetes que governaram com Câmaras eleitas por variantes do regime de listas frente ao mandato médio daqueles que exerceram sua função diante de Câmaras eleitas através das legislações "distritalizadas" (Círculos de 1, de 3 e "Lei Saraiva"). Para efeito do cálculo, dicotomizou-se o regime eleitoral vigente no Segundo Reinado em dois grandes blocos associados às "chapas" e aos "distritos", respectivamente.

Assim, com a legislação de listas em bloco, o tempo de permanência média no poder dos ministérios que governaram diante de câmaras escolhidas por aquele regime foi de 17,45 meses, contra 14,65 meses dos gabinetes que se relacionaram com legislativos "distritalizados", agora também agrupados para efeito do cálculo dicotomizado. Ao governar frente a câmaras baixas "distri- 
Tabela 4 - Permanência Média Gabinetes e Regra Eleitoral (Dicotomizada)

\begin{tabular}{|c|c|c|c|}
\hline Regra Eleitoral & $\begin{array}{c}\text { Duração da Regra (em } \\
\text { meses) })^{\mathrm{I}}\end{array}$ & $\begin{array}{c}\mathrm{N}^{\circ} \text { de Gabinetes } \\
\text { no Período }\end{array}$ & $\begin{array}{l}\text { Permanência Média ou } \\
\text { Mandato Temporal } \\
\text { Médio (em meses) }\end{array}$ \\
\hline $\begin{array}{l}\text { Decreto de } 26.03 .24 \text {, Decreto }{ }^{\circ} .157 \text {, de } \\
\text { 04.05.42, Lei n }{ }^{\circ} 387 \text {, de } 19.08 .46 \text { e Lei do } \\
\text { "Terço" (LISTAS) }\end{array}$ & 244,43 & 14 & 17,45 \\
\hline $\begin{array}{l}1^{\mathrm{a}} \text { e } 2^{\mathrm{a}} \text { Lei dos Círculos e Lei Saraiva } \\
\text { ("DISTRITOS") }\end{array}$ & 337,1 & 23 & 14,65 \\
\hline
\end{tabular}

Fonte: $\mathrm{O}$ autor.

${ }^{\text {I }}$ Critério para a mensuração da duração da regra: vigência estrita de cada legislação, com adaptação, no caso do regime de listas pré-55, ao intervalo estudado no trabalho; critério para a distribuição dos gabinetes por regra eleitoral: legislação vigente à época do termo de início de cada ministério.

talizadas", as equipes ministeriais do Segundo Reinado tiveram encurtados seus mandatos em algo próximo a $16 \%$ do tempo quando comparadas às formações que dependeram de legislaturas de listas.

VII.3. Associação entre a queda de gabinetes por pressão do Legislativo e a vigência de regras eleitorais "distritalizadas"

No que concerne à associação entre regras eleitorais e razões de retiradas de gabinetes, terceiro conjunto de evidências mobilizado aqui, a Tabela 5 apresenta os dados para o período estudado (1840-1889).

$\mathrm{Na}$ coluna inicial, alinham-se os padrões que organizam as razões de substituição dos 37 gabinetes imperiais, nos termos delineados na primeira parte do artigo, os quais são cruzados, em termos de respectivas frequências, com as regras eleitorais em vigor no momento dos episódios, no propósito de se verificar a existência de distribuiçõos de casos mais ou menos uniformes em relação aos regimes eleitorais.

Nesse sentido, vê-se que afastamentos por interferência exclusiva da Câmara (padrão 3) ocorrem quatro vezes sob legislaturas eleitas por listas provinciais (1840-1856), oito vezes diante de Câmaras regidas pelos Círculos (de 1 e de 3), uma vez perante um corpo parlamentar eleito sob a Lei do Terço e seis vezes frente a deputados provenientes do regime eleitoral da Lei Saraiva (distrito de um e eleição em grau único).

Tabela 5 - Razões de Retirada e Regra Eleitoral

\begin{tabular}{|c|c|c|c|c|}
\hline $\begin{array}{l}\text { Razões de Retirada do } \\
\text { Gabinete/Regras Eleitorais }\end{array}$ & $\begin{array}{c}\text { Lista Provincial } \\
1840-56 \\
\text { (4⿳à à } 9^{\mathrm{a}} \text { legislatura) }\end{array}$ & $\begin{array}{c}\text { Círculos de } 1 \text { e de } 3 \\
\text { deputados } 1857-75 \\
\left(10^{\mathrm{a}} \text { a } 15^{\mathrm{a}} \text { legislatura }\right)\end{array}$ & $\begin{array}{c}\text { Lei do Terço } \\
\text { 1876-81 }\left(16^{\mathrm{a}} \text { e } 17^{\mathrm{a}}\right. \\
\text { legislaturas })\end{array}$ & $\begin{array}{c}\text { Lei Saraiva } \\
1882-89\left(18^{\mathrm{a}} \text { a } 20^{\mathrm{a}}\right. \\
\text { legislatura })\end{array}$ \\
\hline $\begin{array}{l}\text { Padrão (3) - Não Interferência } \\
\text { da Coroa, Interferência da } \\
\text { Câmara }\end{array}$ & 4 & 8 & 1 & 6 \\
\hline $\begin{array}{l}\text { Padrão (2) - Interferência da } \\
\text { Coroa, Não Interferência da } \\
\text { Câmara }\end{array}$ & 6 & 2 & 1 & 1 \\
\hline $\begin{array}{l}\text { Padrão (1) - Interferência da } \\
\text { Coroa, Interferência da Câmara }\end{array}$ & 1 & 2 & - & - \\
\hline $\begin{array}{l}\text { Padrão (4) - Não Interferência } \\
\text { da Coroa, Não Interferência da } \\
\text { Câmara }\end{array}$ & 1 & 2 & - & 2 \\
\hline
\end{tabular}

Fonte: $\mathrm{O}$ autor. 
Já substituições de gabinetes classificadas como decorrentes de deliberações exclusivas do trono (padrão 2) acontecem seis vezes sob o regime inicial de listas, duas vezes perante os círculos (de 1 e de 3), uma vez sob a Lei do Terço e outra vez na vigência da Lei Saraiva.

Por seu turno, os afastamentos decorrentes de interferência conjunta de São Cristóvão e da Câmara (padrão 1) se passam uma vez diante de legislaturas escolhidas mediante listas e 2 vezes perante corpos parlamentares "distritais". Por fim, a dissolução voluntária dos gabinetes e casos residuais (padrão 4) se efetua perante as listas (uma vez), os círculos de 1 e 3 (duas vezes) e a Lei Saraiva (duas vezes).

A Tabela 6, por sua vez, replica os dados do quadro anterior e agrupa dicotomicamente os regimes eleitorais vigentes no Segundo Reinado, em termos de sistemas de Listas (Listas Provinciais pré-1855 e Lei do Terço) e sistemas "distritais" (Círculos de 1 e de 3 deputados, Lei Saraiva).

Realizado esse agrupamento, constata-se mais nitidamente a associação entre regras distritais e retiradas por pressão parlamentar (padrão 3). Nesse sentido, dos 19 episódios de substituição ministerial por conflito com o Legislativo, ocorridos no período estudado, 14 (73\%) ocorreram sob a égide de legislaturas eleitas a partir daquele tipo de legislação eleitora ${ }^{32}$.

VII.4. Diferença das relações entre gabinetes e Câmara na $9^{a}$ e $10^{a}$ legislaturas

32 Regras eleitorais "distritais" estiveram em vigor durante $58 \%$ do tempo do intervalo estudado (1840-1889), enquanto que as listas ou "chapas" vigoraram em $42 \%$ do tempo desse período.

${ }^{33}$ As referências completas das fontes que lastreiam a discussão da tramitação orçamentária estão disponíveis por requisição ao e-mail do autor (seferrazz@uol.com.br).
O acompanhamento dessas duas Câmaras - por meio do exame comparado, via anais parlamentares, da discussão e votação dos orçamentos ministeriais em duas legislaturas sucessivas, a primeira eleita por listas, a segunda por círculos ${ }^{33}$ - revelou, no que concerne à primeira das legislaturas (1853-1856), um comportamento disciplinado frente às prioridades governamentais. Em todas as sessões anuais do intervalo assinalado, o ministério aprova a maior parte de suas prioridades, sendo capaz, também, simultaneamente, de manter fora do projeto de lei orçamentária dispositivos considerados inconvenientes.

Já no período 1857-1860 verificam-se sérias dificuldades dos gabinetes em controlar o plenário, materializadas em graves derrotas sofridas pelos ministérios em matéria orçamentária e na incapacidade, em duas das quatro sessões da legislatura (1858 e 1859), de levar a termo a própria tramitação regular da lei de meios dentro do exercício, tendo o Executivo, nessas oportunidades, de contentar-se com prorrogações dos créditos vigentes.

Além disso, a partir da primeira sessão (1857) da $10^{\mathrm{a}}$ Legislatura, a quantidade de emendas e aditivos apresentados ao projeto de lei orçamentária foi, em média, quase três vezes maior do que no período anterior (1853-1856), gerando

Tabela 6 - Razões de Retirada e Regra Eleitoral (Dicotomizando sistemas de Lista e "Distritais")

\begin{tabular}{lcc}
\hline Razões de Retirada & $\begin{array}{c}\text { Sistemas de Lista - Provincial } \\
\text { e Terço }\end{array}$ & $\begin{array}{c}\text { Sistemas “Distritais" } \\
\text { (Círculos de 1 e 3 deputados, Lei Saraiva) }\end{array}$ \\
\hline $\begin{array}{l}\text { Padrão (3) - Não Interferência da } \\
\text { Coroa, Interferência da Câmara }\end{array}$ & 5 & 14 \\
$\begin{array}{l}\text { Padrão (2) - Interferência da } \\
\text { Coroa, Não Interferência da Câmara }\end{array}$ & 7 & 3 \\
$\begin{array}{l}\text { Padrão (1) - Interferência da } \\
\text { Coroa, Interferência da Câmara }\end{array}$ & 1 & 4 \\
$\begin{array}{l}\text { Padrão (4) - Não Interferência da } \\
\text { Coroa, Não Interferência da Câmara }\end{array}$ & 1 & 2 \\
\hline
\end{tabular}

Fonte: $\mathrm{O}$ autor. 
34 Foram apresentadas, em média, 35,75 emendas a cada tramitação orçamentária anual durante a $9^{\mathrm{a}}$ Legislatura (1853-1856). Esse número alcança 93,3 emendas anuais para a $10^{\mathrm{a}}$ Legislatura (1857-60).
35 A referência legal aqui é o Regimento Interno da Câmara (RICD) em sua versão publicada em 1857, a qual reunia os dispositivos vigentes no período de interesse da pesquisa. No que concerne ao ponto abordado no texto, ver o art. 135 , nota 43 , da norma mencionada.

${ }^{36} \mathrm{Na}$ discussão final do orçamento, iniciada após o fim da tramitação dos aditivos, não se admitiam emendas para novas despesas (art. 135, nota 43, RICD, 1857). Além disso, o quórum de apoio para aditivos era de cinco deputados, muito inferior ao quórum na discussão final: a terça parte da câmara, calculada em referência ao quórum de votação, cerca de 20 deputados para a $9^{\mathrm{a}}$ e a $10^{\mathrm{a}}$ Legislaturas. sérias dificuldades de coordenação para o governo na sua relação com os parlamentares $^{34}$.

No propósito de ajudar a evidenciar as diferenças assinaladas, estimou-se um Índice de Desempenho Legislativo do Gabinete (IDLG), o qual mensura o grau de controle do plenário da Câmara exercido pelos gabinetes no período estudado, gerando resultados, como se mostrará logo abaixo, consonantes com as previsões da hipótese sustentada nesta segunda parte do trabalho.

No contexto mais geral da tramitação orçamentária, que compreendia duas rodadas formais de discussões, escolheu-se estudar aqui a etapa desse processo em que se discutiam e votavam os artigos aditivos (Aas). Esta etapa se iniciava após a discussão e votação inicial das despesas por ministérios e das receitas orçamentárias. Os artigos aditivos (Aas) representavam uma oportunidade adicional de interferência no orçamento para o governo e as comissões orçamentárias e, sobremodo, para os parlamentares.

De modo efetivo, para uns e outros, os aditivos - por força de dispositivos regimentais $^{35}$ - materializavam a última oportunidade para a livre criação de despesas orçamentárias, potencialmente incidentes em qualquer dos ministérios e áreas de atuação governamental, com requisitos modestos em termos de quórum de apoio para as propostas ${ }^{36}$. Daí sua atratividade, expressada no grande número de emendas oferecidas ao orçamento mediante esse instrumento regimental. Entre 1853 e 1860, 423 artigos aditivos foram propostos, perfazendo uma média de 60,4 Aas oferecidas por sessão anual da Câmara. Do total de Aas propostos no período, $76 \%$ (321) foram oferecidos por deputados, enquanto que 24\% (97) se originaram de comissões.

Para o governo, os aditivos ofereciam oportunidade para correções técnicas ou para inserir medidas decididas (ou finalizadas) após a confecção da peça orçamentária.

Para os deputados, os aditivos eram uma janela institucional para buscar reforçar e/ou alterar políticas públicas já em andamento ou mesmo para criar novas políticas, de cunho geral ou setorial, que disputavam as prioridades dos ministérios incumbentes. Os aditivos propiciavam também o terreno ideal para a proposição, por parlamentares, de medidas de cunho particularista, muitas das quais direcionadas à satisfação de clientelas geograficamente determinadas, em geral coincidentes com as bases eleitorais dos proponentes, suas constituencies.

Pela janela de oportunidade que abria e em razão da atratividade com que se revestia, sobretudo aos olhos de deputados e representações provinciais, ávidos por melhorarem suas participações no bolo orçamentário do Império e/ou adequarem as políticas às suas respectivas preferências, a tramitação dos aditivos era um desafio ao gabinete, em termos de sua capacidade de coordenar o plenário da Câmara em torno de suas diretrizes centrais.

Para o governo, tratava-se de, simultaneamente, garantir a aprovação de Aas de seu interesse e derrotar aditivos indesejáveis. Daí que, nas oito sessões legislativas estudadas (quatro por cada legislatura), essa tenha sido uma conjuntura que conduzia as lideranças do gabinete a pronunciarem-se buscando influenciar o comportamento do plenário. Entre 1853 e 1860, durante a tramitação em foco, presidentes do Conselho e ministros revezaram-se, na tribuna da Câmara, com diversos parlamentares, expondo a posição do gabinete em termos de apoio ou oposição aos aditivos apresentados. Por essas razões, a análise da tramitação dos Aas constitui um processo privilegiado para mensurar o grau de controle do gabinete sobre o plenário.

Como método para levar a cabo a análise, organizou-se, em cada um dos anos estudados, o conjunto dos aditivos propostos em três diferentes domínios 
37 Para gerá-lo, relativamente a cada ano de interesse, dividem-se por 100 os valores das taxas de aprovação nos domínios 1 e 3, expressos em percentual, e subtraem-se os valores registrados no domínio 3 daqueles constantes do domínio 1.

\section{VII.5. Síntese do argumento}

\footnotetext{
${ }^{38}$ Em 1858 e 1859 os gabinetes não aprovaram novo orçamento, recorrendo a prorrogações. A não votação
}

ou subconjuntos, em função, justamente, do apoio, da oposição ou da neutralidade demonstrada, de modo expresso ou implícito, pelos gabinetes frente a essas proposições.

Trabalhou-se, portanto, com os seguintes domínios ou subconjuntos, assim caracterizados:

Domínio 1: agrupa artigos aditivos sustentados, de modo expresso ou implícito, pelo governo;

Domínio 2: abarca os aditivos para os quais não foi possível encontrar, de modo expresso ou implícito, um posicionamento do gabinete; abrange, igualmente, episódios de ambiguidade, quando não se diagnosticou o sentido preciso da recomendação governamental; por fim, inclui-se aqui, também, casos de "liberação", quando o ministério entrega efetivamente a decisão ao plenário;

Domínio 3: abrange Aas para as quais houve manifestação contrária do governo.

Dos três domínios analíticos construídos, apenas os domínios 1 e 3 são informativos para a mensuração do grau de controle do gabinete sobre o plenário nessa etapa do processo orçamentário. Buscou-se, portanto, na medida do possível, minimizar o enquadramento de proposições no domínio 2.

A utilização desse método permitiu mensurar, para cada sessão anual examinada, taxas percentuais de aprovação de aditivos por diferentes domínios, dando ensejo ao acompanhamento simultâneo do grau de êxito dos gabinetes incumbentes tanto em aprovar emendas de seu interesse como em rejeitar aquelas ajuizadas como indesejáveis. Em princípio, portanto, o grau de controle do governo sobre as decisões do plenário foi tanto maior quanto mais altas as taxas de aprovação verificadas no domínio 1 (aditivos recomendados pelo ministério) e mais baixas as taxas de aprovação aferidas no domínio 3 (Aas rejeitados pelo gabinete).

Essas duas taxas de aprovação são, também, para efeito da análise desenvolvida, transformadas em um único número para cada sessão das legislaturas acompanhadas. Esse indicador vem a ser o Índice de Desempenho Legislativo do Gabinete (IDLG) ${ }^{37}$. Sua função consiste em sintetizar, em único número, a capacidade simultânea, demonstrada pelo governo, de aprovar o que recomendava e de garantir a rejeição do que desaprovava. Nesse sentido, esse indicador varia de "+1" - hipótese em que o gabinete vê endossadas em plenário a integralidade de suas preferências, positivas e negativas - a "-1", quando ocorre o cenário simetricamente inverso.

Examinadas as sessões anuais constitutivas das duas legislaturas em foco e aplicado o método exposto, verificam-se os resultados compilados na Tabela 7, os quais especificam os IDLGs por sessão e as suas médias por legislatura ${ }^{38}$.

A partir dos dados da Tabela 7 , conclui-se que a $9^{\mathrm{a}}(1853-1856)$ e a $10^{\mathrm{a}}$ legislaturas (1857-1860) apresentaram comportamentos diferentes no que concerne a tramitação orçamentária, chancelando positivamente as expectativas da hipótese sustentada no texto. Em outras palavras, nos termos do IDLG, a legislatura "distritalizada", como previsto, mostrou graus bem mais precários de sustentação aos ministérios incumbentes, quando da tramitação orçamentária, em comparação com a Câmara escolhida sob as "chapas".

Os quatro conjuntos de evidências apresentados lastreiam o argumento de que a mudança no regime eleitoral dificultou o controle do plenário da Câmara pelos governos no Segundo Reinando, tornando, na melhor das hipóteses, mais custosa e delicada a aprovação de suas agendas. 


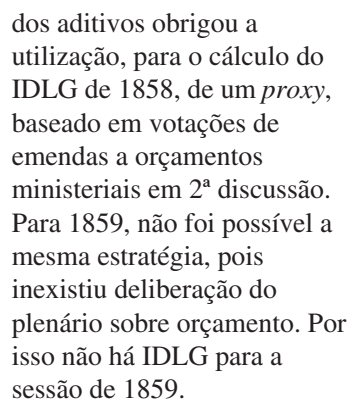

\section{Conclusões}

Tabela 7 - Índice de Desempenho Legislativo do Gabinete (IDLG) na $9^{\mathrm{a}}$ e $10^{\mathrm{a}}$ Legislaturas, Sessões e Média Geral por Legislatura

\begin{tabular}{lc}
\hline Sessões & IDLG \\
\hline $18539^{\mathrm{a}}$ & $+0,857$ \\
$18549^{\mathrm{a}}$ & +0.875 \\
$18559^{\mathrm{a}}$ & $+0,546$ \\
$18569^{\mathrm{a}}$ & +1 \\
$185710^{\mathrm{a}}$ & $+0,430$ \\
$185810^{\mathrm{a}}$ & $+0,338$ \\
$185910^{\mathrm{a}}$ & - \\
$186010^{\mathrm{a}}$ & $+0,790$ \\
Média $9^{\mathrm{a}}$ Legislatura (1853-6) & $+0,819$ \\
Média $10^{\mathrm{a}}$ Legislatura (1857-60) & $+0,519$ \\
\hline
\end{tabular}

Fonte: $\mathrm{O}$ autor, a partir dos Anais da Câmara.

Mais do que isso, as informações levantadas mostram que o tempo de exercício no poder dos diferentes gabinetes ficou mais curto e a sua própria sobrevivência se afigurou mais difícil depois da troca de sistema eleitoral. Em uma palavra, a capacidade de estabelecer relações cooperativas entre Executivo e Legislativo diminuiu com as inovações institucionais introduzidas no sistema eleitoral na segunda metade da década de 1850.

A instabilidade dos ministérios - característica conhecida do Segundo Reinado - é aqui nesta parte do texto vinculada a uma de suas principais (e até hoje desconsideradas) raízes. Não se tratou, portanto, de efeito derivado essencialmente das idiossincrasias, do cálculo ou do bom senso (variam as avaliações consoante se alteram as opiniões sobre o personagem histórico) de uma figura poderosa como Pedro II que pairava acima dos demais poderes, como até hoje parte da literatura sustenta. Nem tampouco da força de uma pequena elite reunida no Conselho de Estado e no Senado da qual a Coroa, revestida das prerrogativas institucionais do Moderador, seria representante, como asseguram outros estudiosos.

Ainda que se conceda que os fatores acima aludidos tenham desempenhado um papel relevante, o que se mostrou é que a fragilidade dos governos do período se associou, primordialmente, às relações de competição e conflito entre Executivo e Câmara dos Deputados. Esta última tensão, por sua vez, foi em grande parte o efeito das regras eleitorais originalmente introduzidas pelo marquês de Paraná na década de 1850 em sua política de "conciliação". Feitas as contas, tudo isso reconfigura o peso relativo das variáveis responsáveis por esse aspecto central do regime imperial - a trajetória dos seus gabinetes abrindo caminho para novas leituras da história política do Segundo Reinado.

Mais do que voltar aos achados principais da pesquisa, já apresentados no desenvolvimento do trabalho, a conclusão deste texto alinha alguns breves comentários sobre o tipo de empreitada intelectual que se buscou realizar aqui e o seu potencial para animar futuras investigações.

O que se pretendeu foi revisitar, com as ferramentas analíticas contemporâneas da Ciência Política, importante (e vasto) período da história política brasileira não habitualmente frequentado pelos praticantes da disciplina. Mais exatamente, a lente analítica foi focada no exame da dinâmica de funcionamen- 
to de certas instituições-chave do arranjo político do Segundo Reinado da experiência monárquica. Buscou-se combinar o conhecimento acumulado sobre a época, em registros os mais diversos, com os tipos de indagação teóricoconceituais e o compromisso com a fundamentação empírica característicos da Ciência Política consoante praticada hoje na tradição neoinstitucionalista.

Ao captar, nesse trajeto, que o comportamento dessas instituições destoava do que o conhecimento cristalizado até hoje sustenta, o texto termina por alcançar um patamar mais amplo do que o previsto no início do empreendimento, qual seja, ser capaz, por seus resultados, de convidar, persuasivamente, espera-se, a uma reavaliação geral do funcionamento do sistema político brasileiro no Segundo Reinado, tarefa aberta aos que concordarem em se aventurar pela senda aqui preliminarmente traçada.

Esse é talvez o horizonte que fornece a principal motivação para empreender o tipo de estudo aqui ensaiado, a saber, a esperança ou a aposta na possibilidade de desvelar inéditas perspectivas de compreensão do processo político a partir da visita a determinadas fases históricas do Estado brasileiro que permanecem praticamente inexploradas até hoje pelos cientistas políticos.

O trabalho de revisitar o passado, eventualmente fazendo emergir como plausíveis novas interpretações de dinâmicas político-institucionais, traz pelo menos em potência a possibilidade de encapsular reverberações significativas para a própria compreensão dos desafios contemporâneos.

Naturalmente, toda a empreitada que esse texto buscou sintetizar está sujeita - tanto no método como nos resultados - às críticas, qualificações e refutações advindas de pesquisas futuras e que poderão, como esta, se beneficiar do conhecimento acumulado. Não é o destino das nossas hipóteses e eventuais conclusões o que realmente interessa, mas a eventual atratividade do caminho esboçado para se chegar até elas. Se este for de valia, pouco importa a fortuna particular de esforços específicos. Pois o propósito de estimular a disciplina a mergulhar - com suas ferramentas e procedimentos peculiares - em amplos territórios de investigação não desbravados terá sido alcançado.

Sérgio Eduardo Ferraz (seferrazz@uol.com.br) é Doutor em Ciência Política pela Universidade de São Paulo (USP). Vínculo Institucional: Secretaria da Fazenda, Recife, Pernambuco, Brasil.

\section{Referências}

Backes, A.L., 2006. Fundamentos da ordem republicana: repensando o Pacto de Campos Sales. Brasília: Editora Plenarium. Barman, R.J., 1988. Brazil. The Forging of a Nation, 1798-1852. Stanford: Stanford University Press. 1999. Citizen Emperor. In . Pedro II and the Making of Brazil, 1825-1891. Stanford: Stanford University Press.

Holanda, S.B., ed., 1985. História Geral da Civilização Brasileira. V. 7: O Brasil MONÁRQUICO: Do Império à República. São Paulo: Difel. 2010. Capítulos de História do Império. São Paulo: Companhia das Letras.

Cain, B.; Ferejohn, J. \& Fiorina, M., 1987. The Personal Vote: Constituency Service and Electoral Independence. Cambridge, MA: Harvard University Press.

Cardoso, F.H., 1985. Dos governos militares a Prudente-Campos Sales. In B. Fausto, ed. História Geral da Civilização Brasileira. V. 8: O Brasil Republicano: estrutura de poder e economia. São Paulo: Difel.

Carvalho, J.M., 2002. Cidadania no Brasil: o longo caminho. Rio de Janeiro: Civilização Brasileira. ,2006. A construção da ordem: teatro de sombras. Rio de Janeiro: Civilização Brasileira. 2007. Dom Pedro II. São Paulo: Companhia das Letras.

Costa Porto, J.A., 1985. O Marquês de Olinda e o Seu Tempo. Belo Horizonte/São Paulo: Itatiaia/Edusp.

Cox, G. \& McCubbins, M.D., 1993. Legislative Leviathan: Party Government in the House. Berkeley: University of California press.

Diermeier, D. \& Krehbiel, K., 2003. Institutionalism as a Methodology. Journal of Theoretical Politics, 15(2), pp. $123-144$. DOI: $10.1177 / 0951629803015002645$

Dolhnikoff, M., 2005. O pacto imperial: origens do federalismo no Brasil. Rio de Janeiro: Globo Editora.

Faoro, R., 2001. Os donos do poder. São Paulo: Globo Editora. 
Fausto, B., 2006. História do Brasil. São Paulo: Edusp.

Ferraz de Carvalho, O., 2012 [1933]. Sistema parlamentar: história constitucional e política. São Paulo: Editora Piratininga. Figueiredo, A.C.A., 1981 [1898]. Oito anos de parlamento. Brasília: Editora da UnB.

Fiorina, M., 1989. Congress: Keystone of the Washington Establishment. New Haven: Yale University Press.

Graham, R., 1997. Clientelismo e Política no Brasil do Século XIX. Rio de Janeiro: Editora da UFRJ.

Iglésias, F., 2004. Vida política, 1848-1868. In S. Buarque de Holanda, ed. História geral da civilização brasileira. V. 5: O Brasil Monárquico: reações e transações. São Paulo: Difel.

Javari, B. 1962 [1889]. Organizações e programas ministeriais: regime parlamentar no Império. Rio de Janeiro: Ministério da Justiça e Negócios Interiores/Arquivo Nacional.

Krehbiel, K., 1991. Information and Legislative Organization. Ann Arbor: The University of Michigan Press.

Lamounier, B., 2005. Da Independência a Lula: dois séculos de política brasileira. São Paulo: Augurium.

Leite, B.W.C., 1978. O Senado nos anos finais do Império, 1870-1889. Brasília: Senado Federal.

Lessa, R., 1988. A invenção republicana. São Paulo: Vértice.

Limongi, F., 2002. O novo institucionalismo e os estudos legislativos: a literatura norte-americana recente. Tese de Livre-Docência. São Paulo: Universidade de São Paulo.

2003. Formas de governo, leis partidárias e processo decisório. BIB, 55, pp.7-40.

2011. The Puzzle of Commanding: The Exercise of Moderating Power. In Colloque International on The Neutral Third

Party in Conflict Resolution. Paris.

Mayhew, D., 1974. Congress: The Electoral Connection. New Haven: Yale University Press.

Nabuco, J., 1949. Um estadista do Império: Nabuco de Araújo. 4 v. São Paulo: Instituto Progresso Editorial.

Needell, J., 2006. The Party of Order: The Conservatives, the State, and Slavery in the Brazilian Monarchy, 1831-1871. Stanford: Stanford University Press.

2009. Formação dos partidos políticos no Brasil da Regência à Conciliação. Revista Eletrônica Almanack Brasiliense, 10 , pp.5-22.

Oliveira Vianna, F.J., 1929. O ocaso do Império. São Paulo: Editora Melhoramentos.

Pereira de Castro, P., 2004. A reação monárquica: política e administração de 1840 a 1848 . In S. Buarque de Holanda, ed. História geral da civilização brasileira. V. 4: O Brasil Monárquico: dispersão e unidade. São Paulo: Difel.

Pereira da Silva, J.M., 2003. Memórias do meu tempo. Brasília: Senado Federal.

Pinho, W., 1930. Políticos e política no Império. Rio de Janeiro: Imprensa Nacional. , 1937. O Barão de Cotegipe e o seu tempo. São Paulo: Companhia Editora Nacional.

Santos, J.M., 1930. A política geral do Brasil. São Paulo: J. Magalhães.

Santos, W.G., 2013. O sistema oligárquico representativo da Primeira República. Dados, 56(1), pp.9-37. DOI: 10.1590/S0011-52582013000100002

Shugart, M. \& Carey, J., 1992. Presidents and Assemblies: Constitutional Design and Electoral Dynamics. Cambridge, UK: Cambridge University Press.

Souza, F.B.S. 1979 [1872]. O sistema eleitoral no Império. Brasília: Senado Federal.

Tavares de Lyra, A., 1979. Instituições políticas do Império. Brasília: Editora da UnB.

\section{Outras fontes}

Brasil, 1824. Constituição do Império. Presidência da República. Disponível em: http://www.planalto.gov.br/ccivil_03/Constituicao/Constituicao24.htm. Acesso em: 30 maio 2017.

Brasil. Anais da Câmara dos Deputados (ACD). Versão Eletrônica. Site da Câmara. Disponível em: http://imagem.camara.gov.br/diarios.asp. Acesso em: 30 maio 2017.

Brasil, 1857. Regimentos Internos da Câmara dos Deputados. Arquivos da Câmara dos Deputados. Brasília. 
The Political Dynamics of the Empire: Instability, Offices and House of Representatives (1840-1889)

\begin{abstract}
The article deals with the imperial politics in Brazil. Its main contribution is to outline an alternative understanding of the institutional dynamics of the "parliamentarism" prevailing at the time, suggesting the failure of the classical explanation of the period. New hypotheses are proposed on two issues: (i) government instability in the Second Empire (1840-1889) and (ii) the nature of the relationship between the Cabinet and the House of Representatives in the period. As for governmental instability ( 37 offices in about 50 years), the research strategy consisted of examining, through literature produced from various canons and Proceedings of the legislature, all the episodes of ministries replacement, including those involved in partisan alternation, to map the reasons associated with each withdrawal. This made it possible to construct a typology of the phenomenon, with the criteria of the presence or absence of intervention of the Crown and / or of the House at the ministerial replacements. The main result achieved shows that both the instability of ministries as alternating between parties resulted primarily from conflicts between the executive and the legislature, especially the House. This finding challenges interpretations that emphasize the role of the Crown in replacing governments. The conflict between the cabinets and the House led to the second question, which deals with this tension. It explores the hypothesis that the introduction of new electoral rules ("distritos"), replacing lists ("chapas"), in the context of an institutional arrangement characteristically "centrifugal", changed important incentives - which worked as mainstay "centripetal" system - for relevant political actors. The change has exacerbated the disputes between ministries and legislatures, contributing to explain the phenomenon of instability. The hypothesis is supported by various evidence: monitoring the proceedings and vote in the House eight draft budgets between 1853 and 1860 , in legislatures elected by different rules, exercise indicator of unequal ability of governments to pass their agendas under different institutional circumstances, confirming the ministerial weakening when crossing lists for "districts"; the lower average tenure of governments who ruled against legislatures "distritalizadas"; association between the fall of cabinets by legislative pressure and the validity of electoral rules "distritalizadas; convergence of sources and literature to emphasize the "centrifugal" consequences of the change of electoral system. Treading these pathways, the article innovates by proposing new interpretations of parliamentary experience of the Second Empire and by suggesting the fertility, to political science, of a research agenda that approximates periods of history Brazil's underexplored.
\end{abstract}

KEYWORDS: ministerial instability; Empire; Second Reign; Executive-legislative relations; electoral rules.

This is an Open Access article distributed under the terms of the Creative Commons Attribution Non-Commercial License which permits unrestricted non-commercial use, distribution, and reproduction in any medium provided the original work is properly cited. 